\title{
Os vidros romanos do Castelo de Castro Marim
}

\author{
Carlos Pereira, Ana Margarida Arruda, Ricardo Silva \\ (UNIARQ - Centro de Arqueologia da Universidade de Lisboa)
}

Recibido: 20/11/2014

Revisado: 10/12/2014
Aceptado: 20/12/2014

Publicado: 30/05/2015
RESUMO

O conjunto de artefactos de vidro recolhido nas várias campanhas de escavação levadas a efeito no Castelo de Castro Marim tinha, à partida, limitações de vária natureza que se prendem com a ausência de contextos estratigráficos seguros e com a elevada fragmentação das peças analisadas. Esta última contribuiu para a dificuldade da classificação de alguns fragmentos, e a primeira impediu atribuições cronológicas com base na associação a outros materiais. Contudo, a datação intrínseca possibilitou verificar que a grande maioria se integra entre meados da primeira metade do século I e o primeiro terço do seguinte, ainda que existam utensílios vítreos posteriores, confirmando-se assim os dados que o estudo de outros materiais tinha proporcionado.

Apesar destes constrangimentos, o estudo dos vidros romanos contribuiu positivamente para a leitura da economia de Baesuris, confirmando-se muito do que já se conhecia da sua dinâmica comercial. Além disso, a distribuição pelas diferentes categorias tornou possível averiguar o tipo de utilização deste material, sobretudo destinado ao consumo de alimentos, sendo escassos os que se destinavam ao armazenamento.

Palavras Chave

Castro Marim; Algarve; Período Romano; Vidros; Economia.
ABSTRACT

The glass artefacts collected in several excavations carried out in Castro Marim Castle had various limitations relate to the absence of preserved stratigraphic contexts and the high fragmentation of the pieces. The latter one had contribute to the difficulty in the classification of some fragments, and the first had limit chronological assignments based on the combination with other materials. However, the typology data allow us the integration of the vast majority between the mid-first half of the first century and the first third of the II, what confirm the data that the study of other materials had provided.

Despite these constraints, the study of roman glasses had contributes positively to the analysis of Baesuris economy, confirming much of what was already known of its commercial dynamics. Moreover, the formal distribution shows the type of use of this material, particularly for food consumption, with few to storage.

\section{KEYWORDS}

Castro Marim; Algarve; Roman glass; High Empire; Roman economy.

carlos_samuel_pereira@hotmail.com 


\section{INTRODUÇÃO}

Durante as escavações arqueológicas levadas a efeito no Castelo de Castro Marim (Figura 1 e 2), realizadas no âmbito de um projecto de investigação dirigido por um de nós (AMA), foi possível recolher vários fragmentos de vidro de época romana. A grande maioria foi encontrada em níveis de deposição secundária, fossas e aterros, constituídos durante a Idade Moderna. Dadas as condições concretas da recolha do espólio, as cronologias propostas são baseadas fundamentalmente nas tipologias disponíveis e nos paralelos verificados.

$\mathrm{O}$ estudo de outros materiais arqueológicos de época romana, concretamente a terra sigillata (Viegas, 2011), as ânforas (Arruda et alii, 2006) e os artefactos metálicos (Pereira, 2008), forneceu já alguns elementos cronológicos que, naturalmente, foram comparados com os que a análise dos vidros facultou.

As dimensões dos fragmentos que pudemos estudar são sempre muito reduzidas. Se é verdade que esta situação é habitual nos sítios de habitat, também é certo que a classificação tipológica de grande parte deles ficou dificultada.
O Castelo de Castro Marim, que ofereceu contextos que permitem estabelecer a sua correspondência à antiga Baesuris, localiza-se no Extremo Oriental do Algarve, na margem direita do estuário do Guadiana, junto à sua foz.

Lembramos que a ocupação do sítio está muito bem documentada para a Idade do Ferro (Arruda, 1999/2000; 2007; 2008; Arruda e Freitas, 2008; Arruda et alii, 2007), tendo sido também muito intensa durante o período Romano-Republicano (Viegas, 2011). O estudo da terra sigillata (Viegas, 2006; 2011), bem como o das ânforas (Arruda et alii, 2006; Viegas, 2011), evidenciou ainda a sua importância durante o Alto-Império, mas permitiu sobretudo perceber que esta, sendo intensa até ao reinado dos flávios, diminuiu consideravelmente a partir do(s) último(s) decénio(s) do século I, momento em que o sítio parece ter sido praticamente abandonado.

Devemos ainda acrescentar que, se os níveis arqueológicos correspondentes à ocupação da Idade do Ferro e Romano-Republicana se apresentam bem conservados, os de época imperial foram os que mais seriamente foram afectados pela constru-

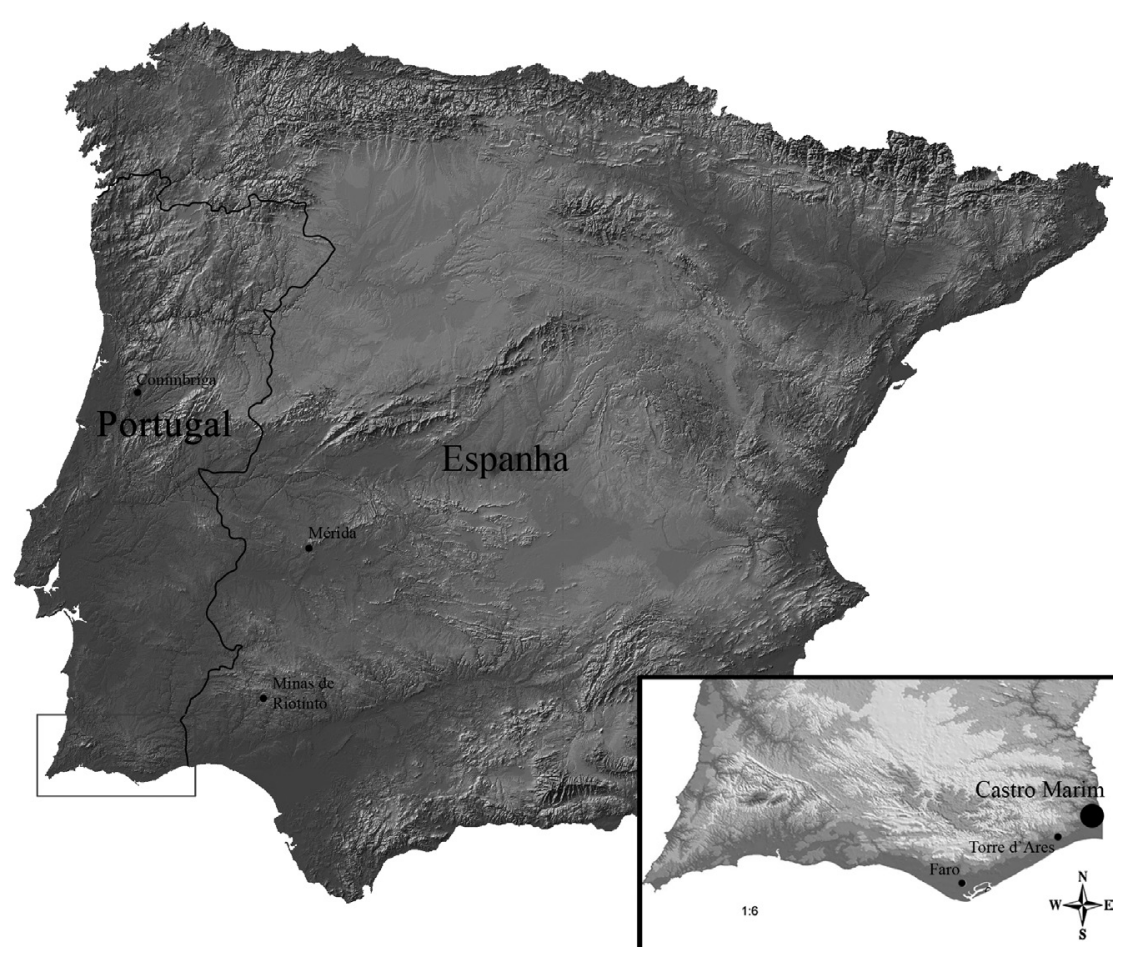

Figura 1. Localização do Castelo de Castro Marim, Portugal, e de alguns dos principais sítios onde se reconheceram as mesmas formas. 


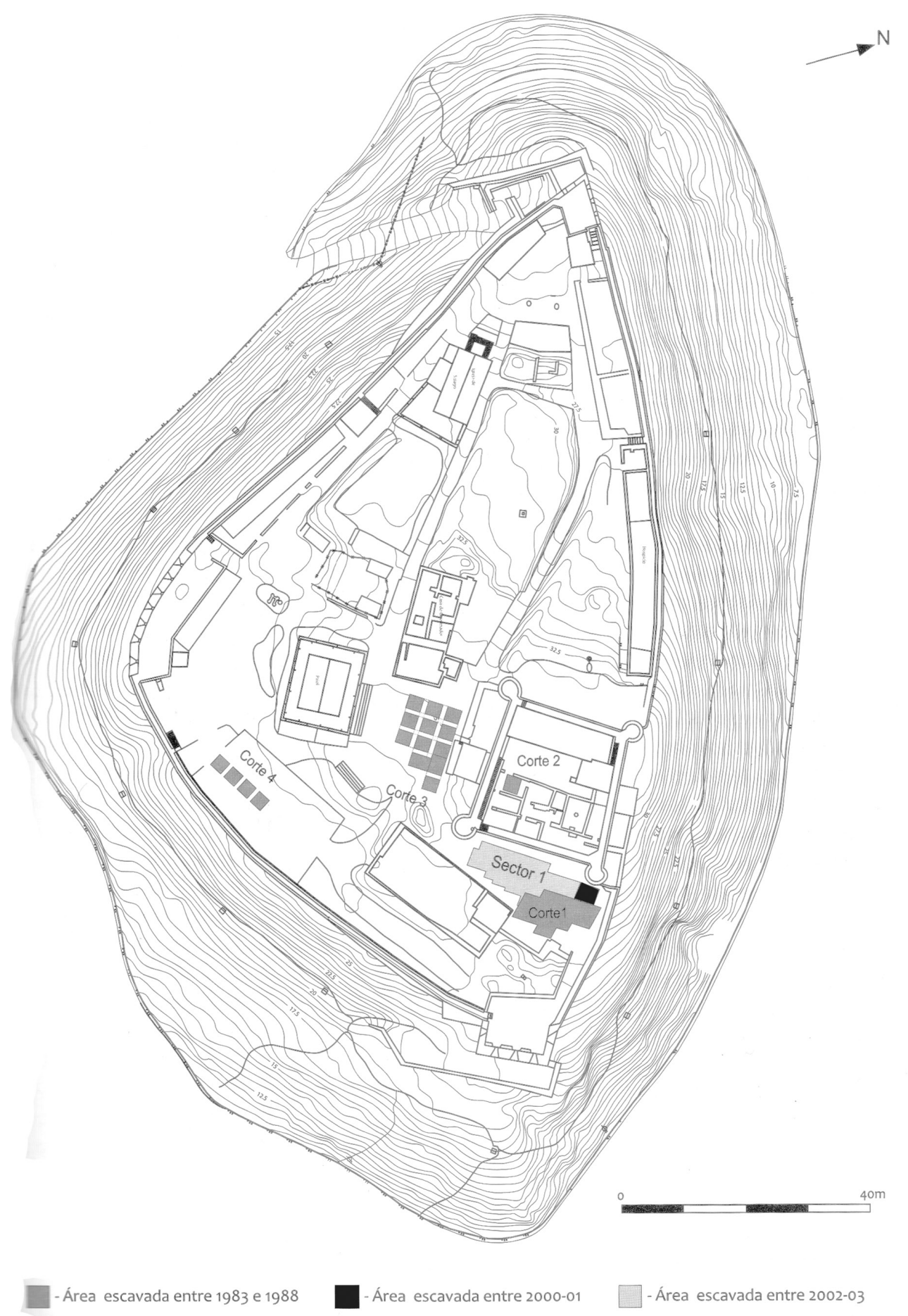

Figura 2. Planta do Castelo de Castro Marim e localização das áreas escavadas (Arruda et alii, 2006, reproduzido em Viegas, 2011). 
ção do Castelo Medieval e pelas remodelações urbanísticas verificadas no seu interior durante a época Moderna. É a este facto que poderá ser assacada a responsabilidade da ausência de contextos arqueológicos seguros para a maioria das peças aqui estudadas, o que, naturalmente, dificultou a atribuição de cronologias baseada na sua associação a outros materiais.

Merecem ainda destaque algumas das opções tomadas na análise destes artefactos. Ainda que, recentemente, se tenha optado pela elaboração de tipologias locais/regionais, esse ensaio não parece ser de todo adequado ao conjunto de Castro Marim. De facto, tanto a elevada fragmentação do conjunto como a ausência de contextos fiáveis para a grande maioria das peças inviabilizam o estabelecimento de uma tipologia própria. Por outro lado, pareceu inapropriado definir grupos morfológicos para este conjunto, que não incorporariam a maioria das formas conhecidas no território algarvio, ignorando as tipologias já estabelecidas, da mesma forma que parecia forçado elaborar uma de âmbito regional que contemplasse formas que são comuns a todo o império. Apenas para dar alguns exemplos, a maioria das morfologias conhecidas no Ocidente, particularmente unguentários, taças e copos, estão também presentes na parte oriental do Império Romano, concretamente nas províncias da Panónia (Leljak, 2012, 123-127), da Moesia Inferior (Chiriac e Botan, 2014, 529-535), da Moesia Superior (Jeremic, 2009, 141-155), ou mesmo no Norte, na Britânia (Cool e Price, 1995).

Mas, mesmo admitindo que os artefactos vítreos não apresentam grandes disparidades morfológicas num tão amplo espaço geográfico, razão que esteve por trás da decisão de não estabelecer uma tipologia local/regional, também sabemos que, frequentemente, circulavam lingotes de vidro bruto, a partir dos quais eram produzidas peças, localmente. Foi esta constatação que motivou a diferenciação entre produção primária e produção secundária (Cruz, 2011, 83-84), sendo esta última possível de realizar em qualquer ponto do Império. Todavia, a distinção entre estas duas produções não é tarefa fácil. Desde logo é evidente que as características do vidro são semelhantes de sítio para sítio, uma vez que a origem da matéria-prima pode ser a mesma, dependendo a qualidade das peças mais da mão do artesão do que propriamente da do vidro. Por outro lado, os próprios aspectos morfológicos não permitem distinguir as produções locais/regionais das im- portadas. Apenas as formas inéditas, com dispersão concentrada a nível local ou regional, possibilitam verificar a existência de produções locais/regionais, o que, por sua vez, não significa a ausência de importação das formas "clássicas".

Neste trabalho, optou-se, portanto, por conciliar morfologia e funcionalidade, metodologia que não é inédita nestes estudos, e que pareceu ser a mais adequada, respeitando-se as tipologias clássicas. Torna-se assim possível verificar a correspondência de formas entre sítios arqueológicos geograficamente distantes. Pelo contrário, a elaboração de tipologias regionais complica a leitura geral do comércio de vidro, pois as formas "clássicas" ganham distintas nomenclaturas, não significando que tenham características distintas ou cronologias diversas.

Embora os estudos específicos destes artefactos tenham, no que se refere às cores do vidro, cada vez mais em consideração nomenclaturas estabelecidas, utilizou-se aqui a tabela de Munsell Color, mesmo estando conscientes que estas referências não se adequam completamente, pelo menos aos vidros translúcidos.

\section{OS MATERIAIS}

\subsection{Metodologia}

O conjunto em estudo é constituído por 61 fragmentos, que abarcam um amplo espaço temporal localizado entre o século I e o século IV d.C. Destes, 43 foram passíveis de classificação tipológica, a qual se tornou impossível para os restantes, dada a reduzida dimensão que apresentam.

A tipologia utilizada foi a que Isings elaborou em 1957, ainda que possamos reconhecer que a sua eficácia actual pode ser questionada, nomeadamente no que se refere às cronologias apontadas para algumas peças. Ainda assim, continua a ser uma obra de referência pela novidade que constituiu a arrumação cronológica efectuada pela autora, apesar de as obras de Kisa (1908) e Morin-Jean (1913) já estarem publicadas. Todavia, e sempre que necessário, apoiámo-nos em outros trabalhos, mais recentes, quando a tipologia de Isings se revelou insuficiente na classificação de alguns vidros deste conjunto.

O estudo que realizámos segue, de certo modo, o modelo aplicado na obra "Vidro Romano do Noroeste Peninsular" (Cruz, 2009), embora com algumas diferenças que, julgamos, simplificam o seu entendimento. Refira-se que este esquema tinha já sido adoptado por Jennifer Price e Sally Cottan (1998), inspirando-se em outros trabalhos que ha- 
viam já experimentado esta mesma metodologia (Lith e Randsborg, 1985).

Assim, os vidros romanos estudados foram divididos, numa primeira fase, em moldados e soprados. Dentro de cada uma destas categorias, as formas foram ainda organizadas entre utilização à mesa, armazenamento de alimentos, recipientes para unguentos ou cosméticos, lâmpadas, fichas de jogo e adereços pessoais. Naturalmente que dentro de cada uma destas categorias as formas são muito variadas, quer cronológica quer morfologicamente.

Quanto aos paralelos, decidimos estabelece-los com Torre de Ares (Balsa), pela proximidade geográfica, e com Conímbriga, por este ser um dos poucos centros produtores de vidros conhecidos no actual território português. Os dados de Bracara Augusta e de Scallabis foram chamados à colação sempre que tal pareceu necessário. Ainda assim, outros sítios foram tidos em consideração nesta análise comparativa.

\subsection{Formas moldadas para utilização à mesa}

Os exemplares moldados não são abundantes neste conjunto. Esta técnica de fabrico apenas se pôde associar aos tipos Isings 3 e 20, que correspondem a taças ou tigelas.

A forma Isings $3(1957,17-21)$ inclui tigelas moldadas a torno, de tendência hemisférica. O bordo é aplanado e vertical, boleado, apresentando no corpo gomos verticais que se estendem desde a base do bordo até ao fundo plano, podendo apresentar outras decorações (Domínguez-Arranz e Ortiz Palomar, 2002-2003). Isings identificou três variantes distintas, baseando-se na altura das peças (variantes a e b) e na forma dos gomos (variante c).

Estas peças ostentam uma grande variedade de cores monocromáticas, opacas e translúcidas. No entanto, a cor predominante é o verde azulado (Fernández Matallana e Crespo Ros, 1996; Caamaño Gesto et alii, 2007; Campos Carrasco et alii, 2009, 1634). Podemos ainda encontrar exemplares policromáticos, nos quais predominam os vidros marmóreos de duas ou três cores, sendo também frequentes os mosaicos millefiori, onde as combinações de cores são mais amplas (Cruz, 2009, II, 20).

Embora estas taças possam coexistir com a forma precedente, mais antiga, parecem ter tido um maior sucesso, o que justificou uma produção mais alargada no tempo. As taças mais antigas deverão ser aquelas que oferecem tonalidades opacas mono ou policromas, sendo mais tardias as translúcidas monocromáticas, de tom verde (5G9/4), como é o caso dos exemplares de Castro Marim. A sua datação compreende o período entre os reinados de Augusto e Trajano, embora se refira o seu aparecimento residual em contextos de século IV (Cruz, 2009, II, 21), estando, contudo, por identificar tais contextos no Extremo Ocidente.

Sendo esta uma das formas que maior sucesso teve durante o século I, não parece despropositado pensar no seu fabrico em território peninsular, nomeadamente na Lusitânia, especialmente no que diz respeito aos exemplares flávios translúcidos. Efectivamente, esta proposta foi já avançada para a área do Noroeste peninsular, onde é defendida a sua produção em Asturica Augusta, Bracara Augusta e Lucus Augusti (Cruz, 2009, II, 21). Também na "faixa pirítica" de Riotinto temos conhecimento de uma elevada presença destas peças (Regalado Ortega et alii, 2014, 1701).

Nos contextos do Castelo de Castro Marim foi possível a recuperação de fragmentos de duas das variantes estabelecidas por Clasina Isings, A (um fragmento, Figura $3, n^{\circ}$ ) e C (dois fragmentos, Figura $3, n^{\circ} 2$ e 3 ).

Os contextos arqueológicos, da variante mais antiga, de Herrera de Pisuerga (Marcos Herrán, 2002, 71) permitiram datá-la da primeira metade do séc. I d.C., o que confirma todas as informações cronométricas apresentadas por Isings (18-19). A sua utilização até final do mesmo século, também já pressentida pela investigadora inglesa com base nos dados de Locarno (Ibidem, 19), ficou igualmente comprovada em Herculano (Scatozza, 1995, $\left.30, n^{\circ} 11\right)$. Ainda que o primeiro sítio corresponda a um estabelecimento militar, importa aqui a função e cronologia da forma, que é coincidente em estabelecimentos militares ou urbanos. De facto, enquanto estas tigelas eram utilizadas em aglomerados habitacionais do Sul, eram também já usadas em acampamentos militares no Norte.

Casos geograficamente mais próximos estão documentados em Conimbriga (Alarcão e Alarcão, 1965, 159, Pl. XXXIV, nº 6), onde a recolha dos diversos exemplares foi efectuada em níveis cláudios, flávios e trajanos, corroborando uma cronologia de século I, e em Augusta Emerita (Caldera de Castro, 1983, 29-30). Em Bracara Augusta, também foi possível constatar a recolha de exemplares desta forma, que, mais uma vez, atestam a cronologia atribuída a este tipo de tigelas (Cruz, 2001, 51, Es- 


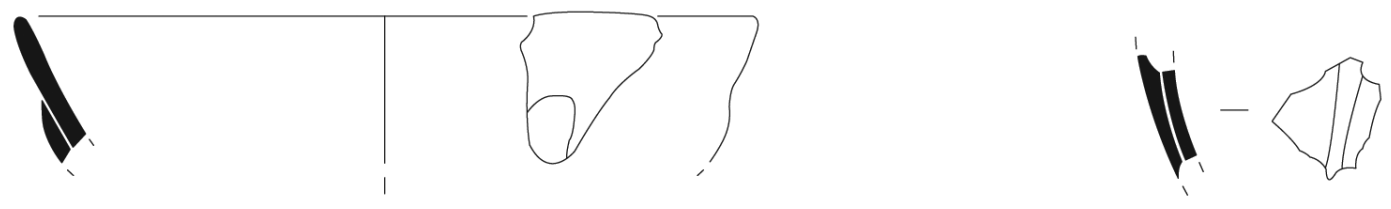

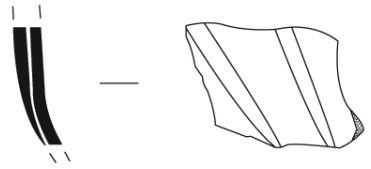

3

Figura 3. Formas moldadas de utilização à mesa.

tampa I, $\mathrm{n}^{\mathrm{0}} 7$ a 13). O exemplar de Balsa (Nolen, 1994, 171, Est. 35, n. ${ }^{\circ}$ VI-7) carece, infelizmente, de contexto arqueológico que permita discutir a sua datação, mas que, apesar disso, foi recentemente abordado por um dos autores destas linhas (Pereira, 2014, 130).

Também o tipo Isings 20 foi fabricado segundo a técnica de moldagem (Girard, 2010, 73 e ss.). Corresponde a uma tigela de bordo aplanado e boleado, com um pé anelar em bisel oblíquo, que tem paralelo nos modelos cerâmicos de terra sigillata, concretamente na forma Ritterling 8 . Na sua maioria, estas peças apresentam cores opacas, como o vermelho ou preto, podendo também surgir exemplares translúcidos de tonalidades esverdeadas (Cruz, 2009, II, 31).

A raridade deste tipo não permite supor a sua produção na parte ocidental do Império Romano, motivo que está por detrás da hipótese da sua origem itálica. Também a cronologia explica esta proposta, tendo as importações ocorrido, sobretudo, entre os reinados de Augusto e Nero (27 a.C.-68 d.C.), ainda que outros autores recuem o limite mais tardio até ao reinado de Cláudio (Berger, 1960, 5).

Os contextos de recolha têm vindo a fortalecer tal datação, como é o caso de Herrera de Pisuerga (Marcos Herrán, 2002, 71) ou de Colchester (Harden, 1947, 302, nº 61). Porém, esta variante pode chegar a alcançar o século I.
No território actualmente português, é escassa a sua representatividade, restrita apenas aos sítios de Bracara Augusta (Cruz, 2001, 52, Estampa II, $\mathrm{n}^{\mathrm{o}} 76$ e 77), onde os exemplares exumados permitiram uma datação precisa, limitada entre o reinado de Augusto e a dinastia Flávia, e de Conimbriga (Alarcão e Alarcão, 1965, 159, Planche XXXIV, $\mathrm{n}^{\mathrm{o}} 11$ e 13). Mais uma vez, os contextos permitiram confirmar a cronologia proposta. Os exemplares recolhidos provêm, sobretudo, de níveis flávio-trajanos. As peças da necrópole de La Dehesa (Regalado Ortega et alii, 2013, 1702) fortalecem estes dados cronológicos.

Infelizmente, o fragmento recolhido no Castelo de Castro Marim (Figura 3, no 4) é proveniente de níveis que não permitem qualquer reforço das cronologias abordadas.

\subsection{Formas sopradas para uso à mesa}

Com as peças produzidas mediante a técnica de sopro, seja em molde ou livremente, o panorama tipológico complexifica-se substancialmente. Se as moldadas estavam sobretudo aptas para o uso à mesa, a partir do momento em que a técnica de sopro é introduzida assistimos a um verdadeiro incremento de novas formas (Pereira, 2012, 64-66), abertas e fechadas, destinadas a preencher as necessidades que, até então, eram supridas pelas cerâmicas. A forma que melhor caracteriza esta realidade 
é a dos unguentários tubulares, que se disseminaram rapidamente por todo o Império, substituindo, por completo, os unguentários de cerâmica, utilizados até então.

Sobre as peças de uso à mesa, que expomos de seguida, a evolução formal apresentada pode, contudo, ser incompatível com o seu desenvolvimento cronológico. Independentemente da opção por um critério, o morfológico, ou pelo outro, o cronológico, as dificuldades permanecem. Assim, pareceu mais favorável uma exposição que tivesse por base os critérios morfológicos, simplificando a tabela tipológica destes materiais.

$\mathrm{Na}$ categoria dos copos cabem três formas da tipologia de Isings, ainda que alguns exemplares, pela sua reduzida dimensão, suscitem algumas dúvidas na classificação atribuída. Esse é o caso, justamente, de um fragmento que considerámos da forma 21. Este tipo inclui copos finos de bordo ligeiramente saliente na parte exterior, de corpo cónico e base em pé anelar. Possuem geralmente decoração lapidada em torno da peça, que pode ser reticulada ou de linhas rectas, tipos decorativos que podem aparecer conjuntamente. A forma lembra os copos do tipo Dragendorff 46, em terra sigillata, com quem partilha a decoração reticulada.

A sua difusão deverá ter decorrido entre os meados do século I e inícios do século II d.C., cronologia baseada nos fragmentos de Vindonissa, recolhidos em níveis datados de 60/75 (Berger, 1960, 68-70). Para os exemplares mais tardios, de final do século I/início do II, são exemplo os fragmentos exumados em Locarno (Simonett, 1941, 84) e em Herrera de Pisuerga (Marcos Herrán, 2002, 102-103). Todavia, temos conhecimento da existência de exemplares mais tardios na parte oriental do Império (Jeremic, 2009, 148-149), datados da segunda metade do século II d.C.

No território actualmente português, este tipo de copo não parece ter sido muito comum, embora existam exemplares em Conimbriga (Alarcão e Alarcão, 1965, 176-177, nº 149 a 157) e em Bracara Augusta (Cruz, 2009, II, 75-76). No sítio da Tarraconense, os vidros da forma 21 estão datados entre final do século I e início, ou mesmo meados, da centúria seguinte. Os exemplares de Conimbriga corroboram esta cronologia, tendo sido recolhidos em estratos flávio-trajanos.

O único exemplar castromarinense identificado, bastante fragmentado, correspondente à base do pé anelar (Figura 4, no 1), e não permite uma leitura contextual, pois foi recolhido em estrato correspondente a uma fossa medieval, aliás, como a maioria dos vidros romanos deste sítio.

Porém, este não foi o único tipo de copo utilizado, durante o século I d.C., na colina do Castelo de Castro Marim. Também os da forma 31 foram aí identificados, correspondendo a copos cilíndricos de bordo aplanado e base plana. Este tipo de peça apresenta uma decoração bastante característica, em relevo, em forma de gota. A técnica de produção utilizada foi, portanto, a de sopro em molde. Alguns investigadores avançaram já a proposta de que as peças com esta decoração se inspiraram na clava que, geralmente, ostenta Hércules (Cruz, 2009, II, 61), sugestão que apoiamos.

A sua cronologia tem vindo a ser fixada na segunda metade do século I, concretamente no início do terceiro quartel, ainda que não seja impossível admitir que era já utilizada em torno a 30 d.C. e se tenha prolongado até início do século II (Isings, 1957, 45-46; Marcos Herrán, 2002, 109-110).

No território actualmente português, estes copos estão presentes em Bracara Augusta com uma cronologia balizada entre os reinados de Nero e Tito (Cruz, 2009, II, 61). Dois fragmentos de parede de vidro soprado sobre molde de Conímbriga foram englobados nesta forma, tendo um deles sido recolhido em estrato associado à construção das termas de Trajano (Alarcão, 1976, 167-168), portanto, mais tardio.

O conjunto vítreo de Castro Marim conta com dois fragmentos incluíveis neste tipo de copos ( $\mathrm{Fi}-$ gura $4, \mathrm{n}^{\mathrm{o}} 2$ e 3 ), de tonalidade translúcida azulada (2.5BG9/4), ambos de contextos de revolvimento, correspondentes à gota em relevo. Não é improvável que possam corresponder ao mesmo recipiente.

O tipo 34a, que abrange copos e tigelas, está representado em Castro Marim por dois exemplares de copos altos (Figura 4, no 4 e 5). São, geralmente, de tendência troncocónica, bordo reentrante de aresta polida ao fogo, base côncava e pé repuxado para fora. Ambas as peças ostentam uma tonalidade translúcida, que varia entre o acastanhado (5YR5/6 ??) e o azulado (2.5BG9/4). Ainda que não possamos garantir a inclusão destes fragmentos na categoria dos copos, essa parece ser a hipótese mais adequada, uma vez que geralmente o fundo das tigelas da mesma forma possui um diâmetro ligeiramente maior.

É possivel admitir para estes exemplares uma cronologia a partir de final do reinado de Nero 
(Alarcão, 1970, 243-244; Nolen, 1994, 173; Cruz, 2009, II, 83). Porém, limitar a sua utilização ao último terço do século I parece demasiado arriscado (Cruz, 2009, II, 83), principalmente tendo em consideração a sua grande variedade morfológica (Antunes, 2000, 162-163). A sua utilização ainda durante o século II parece fazer todo o sentido, estando, aliás, comprovada a sua perduração até ao início do século IV (Harden, 1936, 137, n. 408), situação que poderá justificar a grande variedade formal que apresenta e que é particularmente visível nos exemplares algarvios (Pereira, 2014, 271, 279, 380 e 425). Alguns contextos funerários quer do território português quer do espanhol (Regalado Ortega et alii, 2014, 1706) também apoiam uma cronologia maioritariamente de século II d.C..

A categoria das taças/tigelas conta com exemplares dos tipos 41, 44, 96, 112, 115, 116 e 119 da tipologia de Isings. O primeiro está representado em ambas as variantes, a e b.

A variante a do tipo 41 inclui tigelas de paredes verticais, baixas, com bordo e fundo tubulares. É uma forma bastante similar ao tipo 22 de Isings, a qual corresponde a um prato com as mesmas características, mas de perfil mais baixo (Isings, 1957, 56). O bordo é aplanado, ainda que ligeiramente invertido, tubular e redobrado para o exterior. A base possui uma pequena concavidade no centro e ostenta um pequeno pé, também tubular.

Os dados cronológicos indicam uma produção balizada entre o reinado de Vespasiano e final do século I d.C. (Caldera de Castro, 1983, 32; Cool e Price, 1995, 101-102). No território actualmente português esta peça não parece ter sido amplamente consumida. Infelizmente, não nos deparámos com esta forma nos sítios com os quais estabelecemos paralelos.

Em Castro Marim, foi possível recolher três fragmentos (Figura 4, no 6 a 8), todos pertencentes a bordos tubulares redobrados para o exterior, anunciando um perfil cilíndrico. Apresentam alguma ligeira diferença no que se refere ao seu diâmetro relativamente ao protótipo, o que, no entanto, não nos pareceu ser uma disparidade significativa a ter em consideração. Nenhum dos fragmentos é proveniente de qualquer contexto de deposição primário, tendo dois deles sido recolhidos na mesma fossa medieval onde foram recuperados os fragmentos da forma $3 \mathrm{c}$.

A variante $\mathrm{b}$ do mesmo tipo corresponde também a uma tigela, mas possuí características que a diferenciam da anterior, nomeadamente um perfil mais vertical e de linhas mais direitas, com bordo aplanado, ligeiramente horizontal e exvertido, e base côncava, com um pequeno pé tubular.

Esta variante parece ter sido bastante comum na Península Itálica, mas não é rara no Extremo Ocidente do Império. A cronologia proposta por Isings foi balizada entre meados do século I e final da mesma centúria $(1957,57)$.

$\mathrm{O}$ único fragmento passível de ser integrado neste tipo formal (Figura $4, \mathrm{n}^{\circ}$ 9) é de dimensão muito reduzida, não garantindo, portanto, a classificação avançada, tendo sido recolhido em uma unidade de revolvimento.

As tigelas de vidro contam também com exemplares do tipo 44a. Esta variante é distinguível pelo bordo horizontal, ou em aba inclinada, e base com um pé tubular. Apresenta fortes semelhanças com o tipo 42 e as principais diferenças residem, sobretudo, nas dimensões. De grande importância, parece ser o facto deste recipiente de vidro denunciar fortes semelhanças morfológicas com formas de terra sigillata, nomeadamente com o tipo Dragendorf 29.

A cronologia destas taças é bastante dilatada, ainda que Isings tenha estabelecido o início da sua produção em meados do século I $(1957,59)$, hipótese suportada também em trabalhos de outros investigadores anteriores (Fremersdorf, 1932, 282). Outros ainda têm vindo a recuar esse início para o reinado de Tibério, e até mesmo para época Augustana (Marcos Herrán, 2002, 185; Cool e Price, 1995, 94).

Estes artefactos são particularmente frequentes durante o Alto-Império, pelo que não é de estranhar a sua representação no território actualmente português. Em Balsa (Nolen, 1994, 172, nº vi 11), podemos encontrar um fragmento bastante semelhante aos reconhecidos em Castro Marim. Em Bracara Augusta, foi também possível constatar a presença deste tipo de taças (Cruz, 2001, 72), datadas desde 60/65 até ao terceiro quartel do século II. Infelizmente, Conimbriga não contribuiu com peças deste tipo. Refira-se ainda a existência de fragmentos deste tipo no espólio proveniente da necrópole de La Dehesa (Regalado Ortega et alii, $2013,1702)$, que concordam com os dados cronológicos anteriores.

No sítio algarvio, foi possível recolher três fragmentos enquadráveis nesta forma, os quais apresentam diferenças consideráveis entre si, mas que, mesmo assim, nela foram agrupados. Todos corres- 


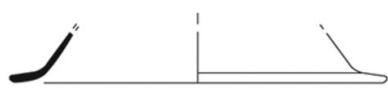

1

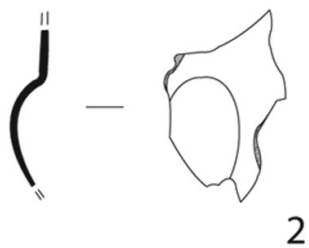

$+$

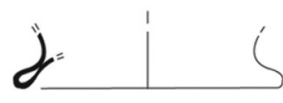

3

4
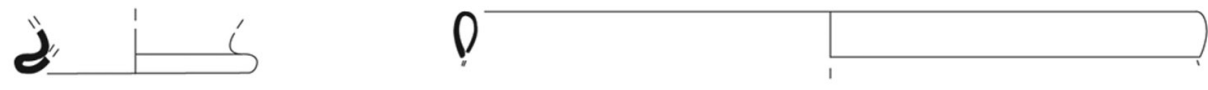

5

6
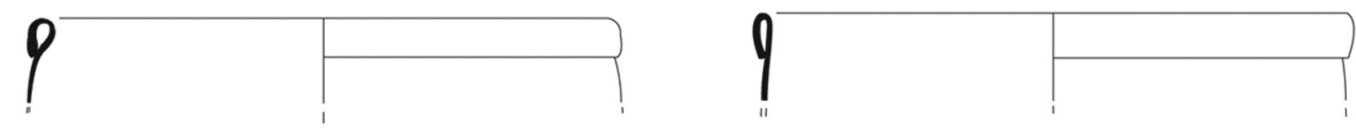

7

8
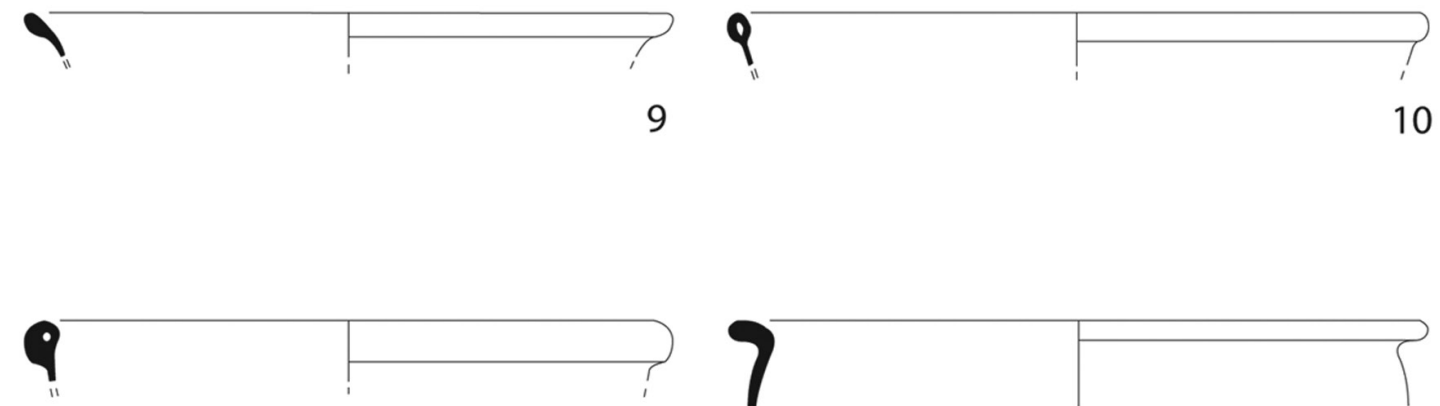

7

11

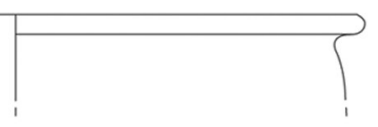

12

Figura 4. Formas sopradas de utilização à mesa. 
pondem a bordos. O orifício sobre um deles (Figura $\left.4, n^{0} 11\right)$, demasiado estreito, não parece delatar uma forma tubular, ainda que o tipo as inclua. Está aplanado internamente, mas é bastante engrossado no seu exterior. Outro caracteriza-se por um bordo engrossado, em aba horizontal, denunciando um perfil ligeiramente invertido (Figura $4, \mathrm{n}^{\mathrm{o}} 12$ ). Finalmente, o terceiro fragmento (Figura 4, $\mathrm{n}^{\mathrm{o}} 10$ ) apresenta a típica forma tubular mais ou menos simétrica.

Mais tardias são outras das tigelas identificadas, como é o caso da forma 96a (Figura 5, no 1 e 2). A forma inclui peças hemisféricas, no caso da variante aqui tratada, de bordo ligeiramente engrossado e exvertido. A base pode ser plana ou ligeiramente côncava. Refira-se ainda que também esta forma pode incluir peças mais pequenas e de perfil mais fechado, as quais cabem na categoria dos copos, como acontece com alguns exemplares reconhecidos em Balsa (Nolen, 1994, 179).

Os contextos de recolha destes artefactos parecem ser amiúde detectados em sítios romanos do Ocidente com uma cronologia de segunda metade do século III e IV (Alarcão e Alarcão, 1965, 106107; Stiaffini, 2005, 44-45; Fremersdorf, 1958, 304), prolongando-se até ao século V. Talvez possamos aqui ter em conta que, por se tratar fragmentos translúcidos (que variam entre 10GY9/6 e 5G9/4), possam ser ainda considerados do século III, ostentando os artefactos mais tardios tonalidades mais carregadas (5GY9/8 ou 5GY9/10), resultado da constante reciclagem do vidro. A mesma realidade é, porém, intuída para outras zonas do Império, quer a Norte (Cool e Price, 1995, 88), quer a Oriente (Leljak, 2012, 129-130), sendo também reconhecida na Península Itálica (Buora et alii, 2009, 54).

A forma 112 de Isings engloba taças cónicas, ainda que se a sua descrição mais correcta seja a de cálice. Possui dois elementos de preensão correspondentes a asas circulares. Estas têm, na parte superior, um pequeno pêndulo horizontal destinado ao apoio do polegar. O bordo deste tipo de peças é exvertido e foi engrossado ao fogo. Outra peculiaridade destas taças reside no pé alto e fino, o qual detém uma pequena saliência junto do fundo, assentando numa base côncava invertida de pé anelar. Regra geral, apresentam decoração incisa.

Os contextos de recolha conhecidos, embora bastante escassos, apontam uma cronologia balizada entre o século III e IV (Isings, 1957, 141), cronologia particularmente atestada em Braga, onde foi datada de momento incerto do século III (Cruz, 2009, II, 147).

Em Castro Marim foi-nos possível reconhecer dois fragmentos desta forma, que devem ter pertencido à mesma peça. O bordo foi ligeiramente engrossado, ao fogo, e dele parte uma asa com as características típicas desta forma (Figura 5, $\mathrm{n}^{\mathrm{0}} 3$ ). Apesar de na tipologia de Isings o protótipo apresentar as asas a meio do corpo, parece-nos credível a sua inclusão neste tipo. Excluindo esse pormenor, a forma do bordo e da asa é em tudo semelhante ao exemplar da tipologia. O segundo fragmento corresponde a um fundo e pé (Figura $5, \mathrm{n}^{\mathrm{O}} 4$ ), que apresenta a típica saliência, localizada, imediatamente, abaixo do fundo. As fortes semelhanças formais e, principalmente, as características técnicas e de qualidade dos fragmentos, podem ser sintoma de que tenham pertencido ao mesmo artefacto.

Mais uma vez estamos incapacitados de tirar qualquer tipo de ilações quanto aos contextos de recolha, pois ambos os fragmentos se encontravam descontextualizados.

Os dois fragmentos que considerámos do tipo 115 (Figura $5, \mathrm{n}^{\mathrm{0}} 5$ e 6) são demasiado pequenos para que a classificação seja concretizada taxativamente. Este tipo inclui taças hemisféricas de bordo tubular exvertido e/ou oblíquo. A base apresentase também de forma tubular, o que se traduz num pequeno pé anelar. Mesmo quando estamos perante artefactos completos é difícil a inclusão neste tipo, pois este apresenta uma ampla gama de variantes formais que podem ostentar perfis de tendência cilíndrica, troncocónica ou bordos com bicos repuxados, como um dos exemplares bracarenses (Cruz, 2009, II, 183).

Mas o que suscitou mais reticências nesta classificação foi a sua tonalidade esverdeada, translúcida (5G9/4). De facto, as cores nestes exemplares tardios, de meados/final do século IV (Isings, 1957, 143), são mais carregadas, como o verde amarelado ou verde acastanhado, ainda que sejam translúcidas. Esta situação pode dever-se ao facto de estas tigelas corresponderem à evolução das do tipo 42 da mesma tipologia, que, sendo embora, maioritariamente, peças sem bordo tubular, podem também apresentar outras com essa característica. Por este motivo não descartamos que os fragmentos da de Castro Marim não possam pertencer ao tipo mais antigo, da segunda metade do século I e II d.C.

As peças da forma 116 de Isings também estão presentes no espólio vítreo castromarinense. Este 


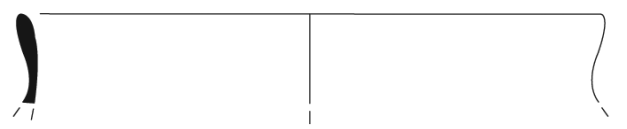

1
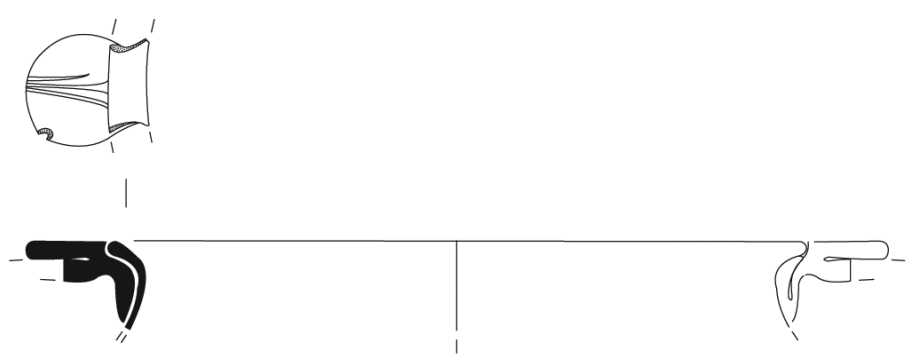

3

a

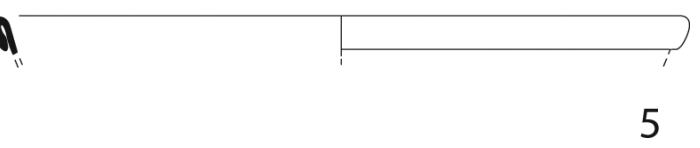

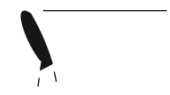

2

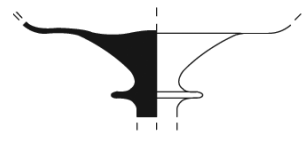

4
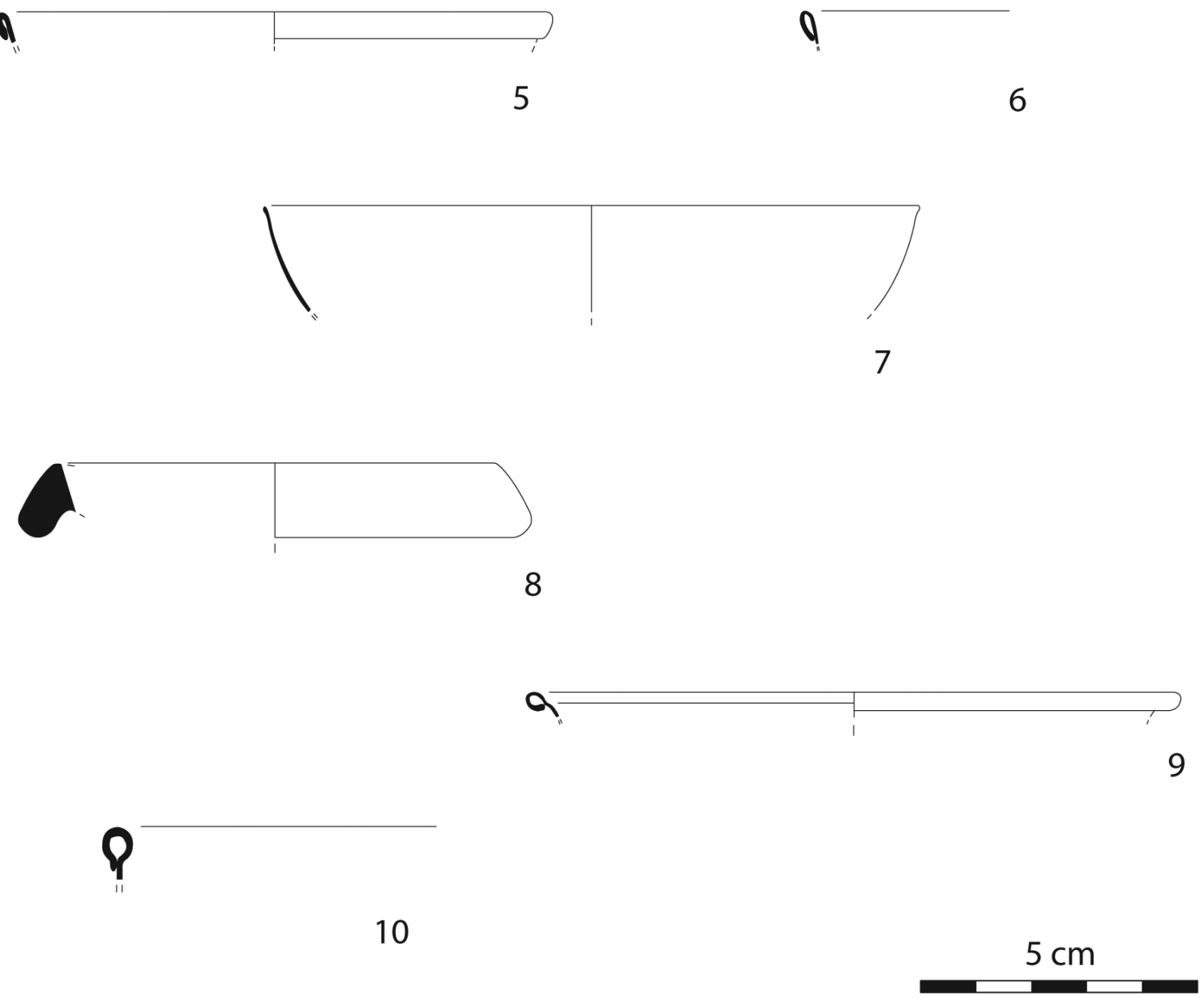

Figura 5. Formas sopradas de utilização à mesa. 
tipo corresponde a tigelas em arco invertido, base convexa, ligeiramente engrossada, e bordo em aresta viva de perfil em "S", geralmente inflexionado para dentro, também denominadas "pratos covos" (Nolen, 1994, 178). Embora estas peças sejam translúcidas, apresentam tonalidades tardias, em tons verdes amarelados (5GY9/8 ou 5GY9/10), como é o caso, ou verdes amarelados escuros. Tendo em conta o facto de esta forma ser bastante comum durante o século IV (Isings, 1957, 144), em todas as províncias do Império, e também durante a centúria seguinte, é frequente a existência de exemplares decorados por abrasão ou gravados à mão, os últimos com especial incidência no século IV (Foy, 1995).

Foi já proposta a produção deste tipo, na versão lisa, no território actualmente português, concretamente no Noroeste (Cruz, 2009, II, 121), estando, contudo, por comprovar se também terá sido produzido na Lusitânia. No território algarvio, apenas temos conhecimento da sua existência em Balsa (Nolen, 1994, 178, $\mathrm{n}^{\mathrm{o}}$ vi 87 a vi 90), correspondendo a uma peça importada.

Em Castro Marim, foi possível a recolha de um exemplar da variante a (Figura $5, \mathrm{n}^{0} 7$ ), que corresponde ao característico bordo aplanado, ligeiramente engrossado e esvasado. Uma das diferenças substanciais entre o exemplar em análise e o da tipologia de Isings reside no diâmetro. No entanto, decidimos não sobrevalorizar este facto, uma vez que é ampla a variedade de tamanhos entre as diferentes peças pesquisadas. O contexto do exemplar recolhido corresponde, mais uma vez, a uma deposição secundária, tendo sido recolhido em um estrato Moderno.

A forma 119 de Isings é, quiçá, uma das mais curiosas. Corresponde a pequenas tigelas exvertidas e de bordo em aba pendente. Também a base deste tipo de peças facilmente se confunde com o corpo da mesma. É uma forma bastante simples e rara, de paredes espessas, confirmando um possível fabrico através da técnica de prensagem em molde.

A cronologia que lhe vem sendo outorgada, apresenta, em nosso entender, bastantes problemas. Segundo a autora da tipologia, os contextos de recolha apontam para uma cronologia balizada entre os séculos III e IV. Todavia, as características deste tipo de peças, a técnica de fabrico utilizada, bem como a precariedade dos contextos de recolha referidos pela autora (Isings, 1957, 149) obrigam a considerar a possibilidade de a sua datação ser mais antiga. De facto, esta parece ser a forma que me- lhor denuncia a necessidade da revisão da tipologia aplicada neste estudo, especialmente se atendermos ao facto de este exemplar ostentar uma tonalidade que é maioritariamente associada ao Alto-Império, verde translúcido (5G9/4), pois, como já se afirmou com base em outros estudos (Cruz, 2009), as cores tardias são sempre mais carregadas.

Infelizmente, esta forma não está presente nos sítios com os que estabelecemos paralelos, situação que pode dever-se à sua errada classificação como fundo de garrafa cilíndrica.

Apesar de bastante fragmentado, foi possível integrar um fragmento de vidro de Castro Marim neste tipo de tigela (Figura $5, \mathrm{n}^{\mathrm{o}} 8$ ). Corresponde a um bordo espesso em aba pendente. Infelizmente, os problemáticos contextos de recolha repetem-se para este exemplar.

Os poucos fragmentos que considerámos pertencentes a pratos também são vítimas dessa circunstância. Repetimos que a maioria dos fragmentos de vidros romanos foi recuperada em unidades estratigráficas de cronologia Medieval ou Moderna.

A forma 19 engloba pratos de base aplanada, bordo tubular exvertido, apresentando um pequeno ressalto na ligação do bordo à parede. Apresenta o perfil oblíquo de uma forma aberta, embora o diâmetro não ultrapasse os $15 \mathrm{~cm}$, com excepção de dois exemplares provenientes de Pompeia em que o diâmetro excede os $28 \mathrm{~cm}$. (Isings, 1957, 37). Não são muitos os contextos em que este tipo de prato foi encontrado, estando, no entanto, a cronologia centrada em meados do século I d.C. (Ibidem).

Notámos uma evidente ausência deste tipo de artefacto no território actualmente português, facto que contribui igualmente para as dificuldades de classificação.

$\mathrm{O}$ único fragmento recolhido apenas conserva o bordo (Figura 5, no 9), que foi incluído nesta forma devido ao facto de apresentar, sob ele, o típico ressalto. A diferença que se verifica em relação ao diâmetro (11,7 cm em Castro Marim; 14 no exemplar de Isings) não pareceu impeditiva deste enquadramento formal. Repete-se a proveniência de um contexto Medieval.

Um outro prato, pertencente à forma 45 , foi identificado no conjunto. Corresponde a um tipo de pratos de perfil baixo, bordo tubular e base redobrada, que possuem uma carena acentuada, localizada imediatamente abaixo do bordo. A base é côncava, ostentando pé anelar redobrado, ligeiramente inclinado para o exterior. 
Os contextos de recolha deste tipo apontam para uma cronologia balizada entre meados e final do século I d.C. - Colchester (Harden, 1947, nº 80 e 81), havendo contudo dados que permitem admitir a sua utilização até ao século III - Karanis (Harden, 1936, 76, nº 117 e 121), ou mesmo IV (Cruz, 2009, II, 179).

Recentemente, foi proposta a sua produção, em momento tardio da ocupação romana, no Noroeste peninsular (Ibidem), proposta que defende a sua produção até ao século $\mathrm{V}$, ainda que admitindo que a maioria destes artefactos são recolhidos em contextos alto-imperiais (Price e Cottam, 1998, 77).

Em Castro Marim, foi exumado apenas um fragmento (Figura 5, n⿳o 10), de dimensões muito reduzidas, deste tipo de prato. A sua integração na forma 45 foi, ainda assim, possível dadas as suas características peculiares, concretamente a sua verticalidade, bem como a forma tubular redobrada, com a especificidade de apresentar também o extremo do bordo, vertical, colado à parede da peça. Infelizmente, as pequenas dimensões do fragmento não permitiram conservar a carena característica desta forma, nem possibilitam retirar conclusões no que se refere às dimensões do diâmetro. Consideramos, contudo, que se trata de um exemplar alto-imperial, especialmente por apresentar uma tonalidade clara translúcida (5G9/4).

\subsection{Formas sopradas para guardar e servir bebidas}

Embora nesta categoria se integrem, maioritariamente, garrafas e jarras, não é obrigatório que aquelas se destinassem a guardar líquidos e estas a servi-los, ou vice-versa. $\mathrm{Na}$ verdade, qualquer das duas formas desempenharia ambas funções.

A esta categoria pudemos associar um fragmento da forma 16 de Isings, que engloba peças de corpo globular, apresentando um bordo horizontal invertido, de perfil triangular, e decoração em bandas horizontais incisas. A distância entre as referidas bandas incisas não é homogénea, podendo a altura entre as mesmas variar.

Os dados estratigráficos existentes permitem datar a produção deste tipo do segundo quartel do século I, sabendo-se, no entanto, que perdura até ao final da referida centúria - Colchester (Harden, 1947, 304; Foy e Nenna, 2001, 158; Price e Cottam, 1998, 171). Outros autores avançaram ligeiramente o seu consumo até início do século II (Cruz, 2009, II, 211). Os exemplares bracarenses foram, aliás, classificados como unguentários. Em abono da verda- de, sabemos apenas que este artefacto se destinava a conter líquidos, desconhecendo-se se estes eram ingeríveis ou não.

Os três fragmentos recolhidos em Castro Marim parecem pertencer à mesma peça (Figura 6, n⿳0 1), ainda que não tenha sido possível a sua colagem. Possuem a superfície picada, com excepção das bandas incisas, as quais apresentam uma distância entre si de, aproximadamente, $1 \mathrm{~cm}$.

Se não podemos garantir qual foi a finalidade da forma antes tratada, podemos assegurar que a 50 corresponde a uma garrafa prismática soprada em molde, que pode fornecer peças baixas ou altas, característica que distingue as variantes da tipologia de Isings. Possuem gargalo de perfil triangular ou horizontal redobrado e base praticamente plana, principalmente a variante "b" (Figura 6, no 3 ). Este tipo de peça é portadora de uma asa em forma de "V" invertido, que arranca do colo e termina no ombro da peça.

Os contextos arqueológicos atestam, como não é de estranhar, uma diacronia cronológica bastante alargada para este tipo de contentor, o que justifica o consideravelmente amplo número de variantes, contrariamente ao que se passa em formas de vida curta. Quer as peças baixas quer as altas aparecem a partir, sensivelmente, de meados do século I d.C. (Isings, 1957, 63-66), podendo ter perdurado até ao século III (Price e Cottam, 1998, 194; Nolen, 1994, 175). Como foi referido anteriormente por outros autores, a diferenciação entre as distintas variantes prismáticas não permite, automaticamente, uma diferenciação cronológica uma vez que algumas devem ter coexistido (Alarcão e Alarcão, 1965, 92).

No Ocidente, este tipo de peças está relativamente bem representada na maioria dos sítios arqueológicos com alguma importância durante o Alto Império. Balsa (Nolen, 1994, 175, nº 45, 46, 47), Scallabis (Antunes, 2000, 182-184, $\mathrm{n}^{0} 31$ a 37), Augusta Emerita (Caldera de Castro, 1983,17) e Conimbriga (Alarcão et alii, 1976, 168-169) são alguns dos locais onde há exemplares confirmados. No último caso, provêm de níveis flávios e também de outros da canalização das termas de Trajano, momento que se supõe ser o de maior consumo (Cruz, 2009, II, 224). Este tipo de garrafas prismáticas está igualmente presente em Bracara $A u$ gusta (Cruz, 2001, 75-76), tendo permitido uma datação de final do reinado de Augusto/início do de Tibério até ao final do século II (Cruz, 2009, II, 224). Também no Museu Municipal de Elvas existe 
um exemplar, proveniente de Cerrado dos Fangueiros, na freguesia de S. Brás de Varche, concelho de Elvas (Alarcão, 1968, 28, nº 46).

No sítio algarvio que tratamos, foi possível recolher dois exemplares destas garrafas, um correspondente a um fundo da variante a (Figura $6, \mathrm{n}^{\mathrm{o}}$ 2), o outro correspondente a um bordo horizontal redobrado da b (Figura 6, n ${ }^{0} 3$ ). Relativamente ao fundo, e embora o seu estado de fragmentação não permita tirar conclusões quanto à variante a que pertence, é seguro que condiz a uma garrafa prismática quadrangular, de base plana.

$\mathrm{O}$ bordo pertenceu indiscutivelmente a uma garrafa deste tipo, uma vez que apresenta aba horizontal redobrada.

Mais uma vez, estamos perante fragmentos provenientes de uma fossa Medieval.

A forma 58 de Isings, com a qual se fez uma correspondência (Figura $6, n^{\circ} 4$ ), acomoda um tipo de jarro ovóide não muito comum durante o Império romano. Possui um bordo horizontal oblíquo, um colo não muito diferenciado do corpo da peça, base côncava e dispõe de uma asa que parte directamente do bordo, que se prolonga, sensivelmente, até meio do corpo.

Os contextos apontam para uma cronologia balizada entre final do século I d.C. e início do seguinte (Isings, 1957, 76-77). Infelizmente, não encontrámos nenhum exemplar nos sítios romanos do Ocidente que possam atestar tal cronologia.

$\mathrm{O}$ fragmento algarvio corresponde a um fundo côncavo que, admitimos, se trata da parte da peça que mais dúvidas tipológicas pode suscitar. As principais características que permitiram o seu enquadramento neste tipo são, essencialmente, o seu perfil e a sua orientação, bem como o diâmetro, que não encaixava em outras formas com tais características.

Igualmente raras em contextos ocidentais são as garrafas ou jarros com relevos, do tipo 78 de Isings, que adquirem, geralmente, a forma de figurações humanas ou vegetais. No caso da variante aqui tratada, variante $b$, assume a forma de uma cabeça humana da qual apenas se conservou parte do rosto. A técnica de fabrico utilizada nestes artefactos era a de sopro em molde.

Os contextos de recolha deste tipo de peças, que não se apresentam aqui de forma sistemática, permitem, no entanto, auferir-lhes uma cronologia balizada entre o século I a.C. e final do século I d.C. (Isings, 1957, 94), embora outros autores prolon- guem a sua datação no Extremo Oriente do Império (Chiriac e Botan, 2014, 531).

No Castelo de Castro Marim recolheu-se um exemplar deste tipo (Figura 6, $\mathrm{n}^{\mathrm{0}} 5$ ), que, apesar de ser de dimensões reduzidas, permitiu a sua classificação por conservar parte do relevo, uma forma humana, que estaria visível num dos lados da peça, visto estarmos aqui a tratar de garrafas quadradas ou hexagonais. O contexto de recolha (um estrato de aterro Moderno) não permite tirar qualquer conclusão sobre a cronologia.

Outro fragmento (Figura 6, no 6) pode corresponder a um contentor de bebidas, sem asas. Referimo-nos às jarras cilíndricas, do tipo 102, de perfil ligeiramente oblíquo, bordo horizontal, com duas pequenas molduras, colo estreito e base côncava.

Uma cronologia do século III tem vindo a ser apontada, podendo persistir, inclusive, até ao século seguinte (Isings, 1957, 120-121). Artefactos deste tipo foram datados em Bracara Augusta (Cruz, 2001, 81) entre os reinados de Augusto/Tibério e o século III, propondo-se ainda uma produção local. Porém, a revisão do mesmo conjunto parece ter revelado que este tipo está apenas documentado na primeira metade do século IV (Cruz, 2009, II, 345).

$\mathrm{O}$ fragmento recolhido em Castro Marim corresponde a um fundo de base côncava e perfil ligeiramente oblíquo, proveniente de um estrato de nivelamento Moderno.

A mesma funcionalidade terá tido uma outra jarra, idêntica e também sem asas, da qual foi possível recuperar parte do bordo (Figura 6, no 7 ). A morfologia do fragmento permite propor que possa corresponder ao tipo 104a de Isings, forma que reúne jarras globulares em que, no caso da variante aqui objecto de estudo, o colo vai ficando cada vez mais estrangulado à medida que se aproxima do corpo da peça. O bordo é ligeiramente invertido, e o colo é consideravelmente alto. O fundo é côncavo, possuindo um pequeno pé anelar, tubular e oblíquo. Ainda que este recipiente seja frequentemente denominado "jarra”, nomeadamente por Clasina Isings (1957, 122-123), também tem sido denominado de "frasco" por alguns autores (Cruz, 2009, II, 345; Alonso Cereja, 2010, 107), ou mesmo unguentário (Alonso Cereja, 2010, 107). Dentro das nomenclaturas adoptadas, jarra parece a mais correcta.

Quanto aos dados obtidos de alguns contextos de recolha, esta forma aparece durante o século III, mantendo-se em uso também durante o século IV (Haberey, 1942, 257; Isings, 1957, 123; Cool e Price, 
Carlos Pereira - Ana Margarida Arruda - Ricardo Silva

39
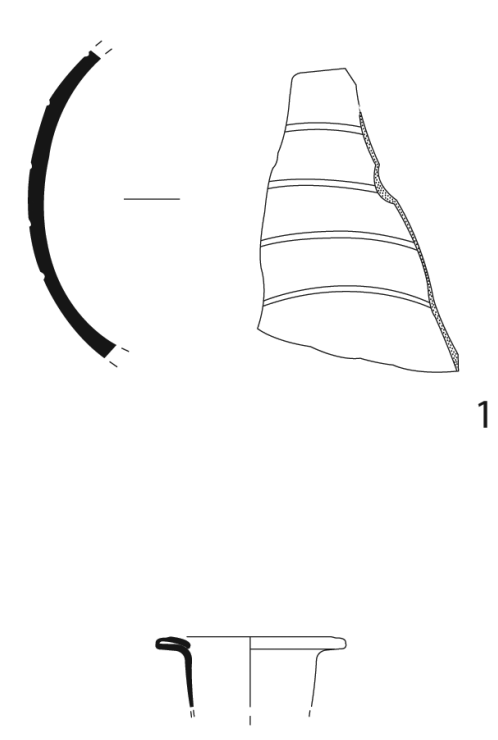

3
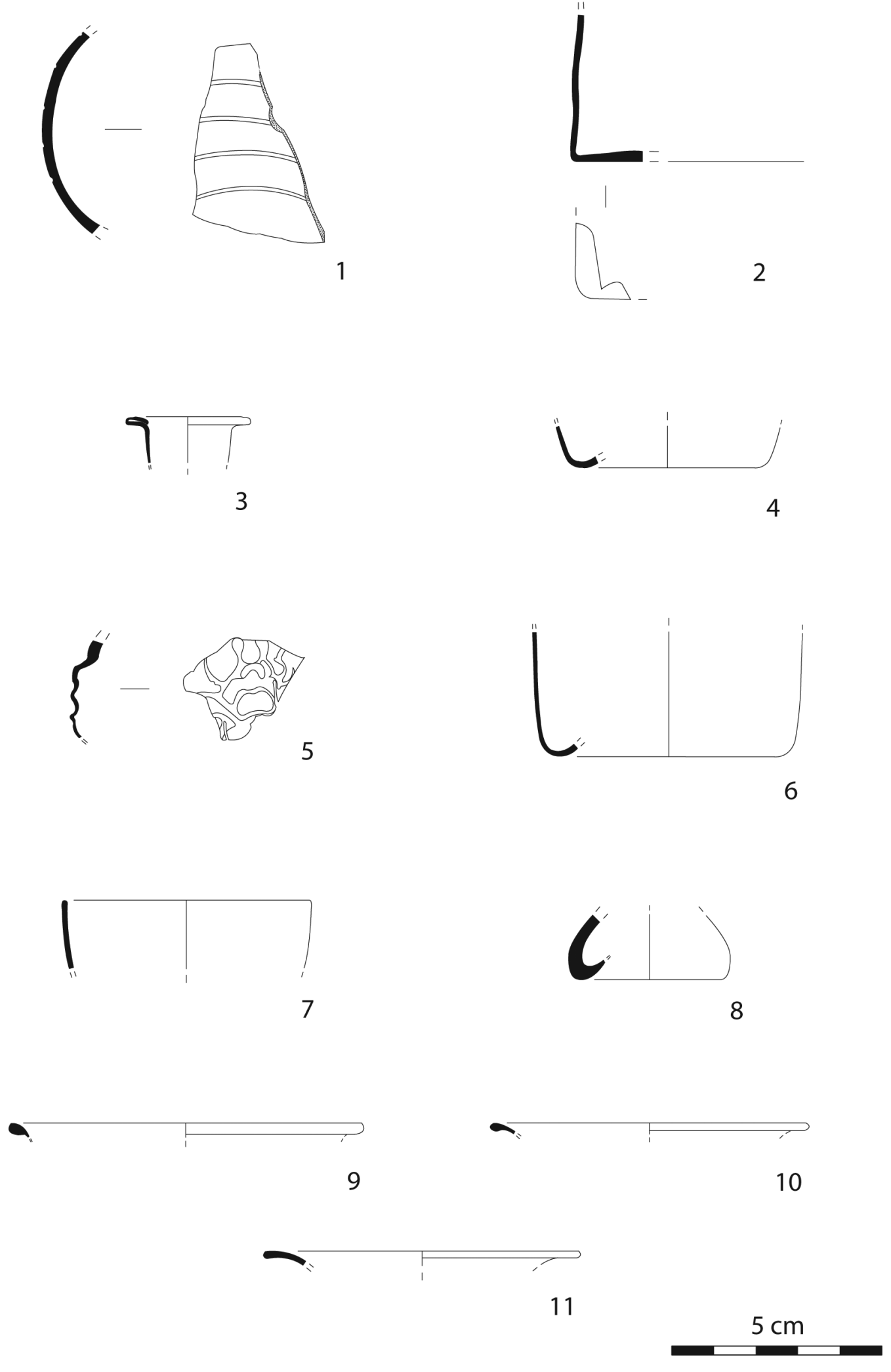

4

6
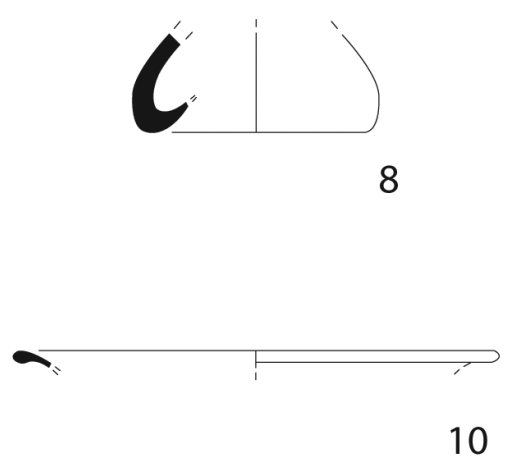

Figura 6. Formas sopradas para guardar e/ou servir bebidas.

Revista OnOBa, 2015, No 03 
1995, 164; Cruz, 2009, II, 345), ainda que se proponha o seu consumo até ao século seguinte (Alonso Cereja, 2010, 107).

No território actualmente português, não deverá ter sido muito comum, estando apenas documentada em Scallabis (Antunes, 2000, 181, $\mathrm{n}^{\mathrm{0}} 27$ ) e em Bracara Augusta (Cruz, 2001, 80; 2009, II, $345)$. No último sítio referido, os contextos de recolha apontam para uma cronologia de século III e inícios de IV, datação que, mais adequadamente, pode avançar para a primeira metade do IV.

$\mathrm{O}$ fragmento aqui em análise foi exumado em um estrato de pavimento de argamassas Moderno, não permitindo corroborar as cronologias avançadas segundo os dados de outros sítios.

Um tipo de jarra deverá ser datado da segunda metade do século IV (Isings, 1957, 143), a forma $114 b$. Tem bordo aplanado, colo alto e vertical, que termina de forma acentuada, mudando de direcção repentinamente, denunciando a separação do colo para o corpo da peça, que se traduz na presença de um ombro. A base é constituída por um pequeno pé anelar, côncavo e estrangulado. Outra peculiaridade deste tipo de peças reside na presença de decoração: pequenas depressões ovaladas no corpo.

Este recipiente não deverá ter sido muito comum nos sítios ocidentais, situação que se pode dever ao seu fabrico e consumo tardio, em um momento de clara retracção económica e social nesta parte do Império.

Em Castro Marim, foi possível classificar um exemplar deste tipo (Figura 6, n⿳0 8), correspondente ao fundo estrangulado, côncavo e de perfil oblíquo. Mais uma vez estamos perante um fragmento que foi recuperado num nível descontextualizado.

Sublinhando mais uma vez as dificuldades que constantemente sentimos ao classificar fragmentos de tamanho tão reduzido, pareceu-nos viável a associação de um pequeno conjunto de três bordos horizontais e com aba pendente (Figura 6, no 9 a 11), à forma $120 \mathrm{~d}$ de Isings. Esta forma recolhe jarras de corpo ovóide, de bordo horizontal engrossado ao fogo, ou em aba pendente, colo estrangulado de perfil pouco acentuado com um pequeno "colar" aplicado. Detém ainda uma base com pé anelar repuxado e asa de perfil triangular, que arranca do bordo e se desenvolve até, sensivelmente, ao meio do corpo.

Clasina Isings, apoiando-se em vários exemplares com contexto de recolha seguro, avança uma datação situada entre o final do século IV e início do século seguinte $(1957,152)$, datação que é seguida por outros autores, ainda que alguns considerem a sua utilização exclusiva durante o primeiro (Rütti, 1991, 57) e outros durante o último (Alonso Cereja, 2010, 106).

No território actualmente português, este tipo de peças é escasso, encontrando-se apenas documentado em Bracara Augusta (Cruz, 2001, 79). Contudo, os exemplares recolhidos neste sítio correspondem à primeira variante. Constatámos ainda a presença desta forma na colecção de vidros romanos do Museu Municipal de Elvas (Alarcão, 1968). Não obstante, também este exemplar não parece corresponder à variante aqui tratada.

\subsection{Formas sopradas para guardar alimentos}

Nesta categoria de recipientes, destinados ao armazenamento de alimentos, cabem sobretudo os boiões e os frascos, ainda que não se possa garantir que alguns se destinassem a conter outros produtos, como os unguentos ou os cosméticos. Como acontece com a maioria das formas de artefactos vítreos, nem sempre os fragmentos que tratamos têm correspondência absoluta nas formas clássicas das tipologias conhecidas. Esta situação é potenciada pelo facto de o vidro ser fabricado livremente (à excepção das sopradas em molde), sendo difícil que cada peça seja rigorosamente idêntica à precedente ou à fabricada posteriormente. No caso dos boiões, esta situação é particularmente visível, o que justifica a existência de abundantes variantes dentro da mesma forma, nem consideradas nas obras de referência (Kisa, 1908; Harden, 1936; 1947; Isings, 1957; Rütti, 1991; Cruz, 2009).

Os boiões da forma 67 não são, apesar de tudo, os que mais problemas de identificação suscitam, mesmo quando lidamos com conjuntos de levada fragmentação, como é o caso. São, geralmente, recipientes simples, de bordo horizontal redobrado para o exterior. Também são frequentemente denominados "urnas", pois não é rara a sua recolha em contextos funerários. O seu uso nesses contextos deve-se à morfologia do corpo, ovóide ou globular, apto a conter as cinzas resultantes das incinerações. Todas as variantes têm a base côncava.

Entre os contextos de recolha que permitiram a obtenção de uma datação fiável, contam-se os de Pompeia (Maiuri, 1933, 460, no 183), datados de final do século I d.C., e de Colchester (Harden, 1947, $305, \mathrm{n}^{\mathrm{o}} 89$ ), datados de meados do mesmo século, tudo indicando uma cronologia de fabrico e de con- 
sumo balizada entre meados do século I e início do II. Alguns autores propõem o seu prolongamento até final do século II, o que estaria demonstrado em Herrera de Pisuerga (Marcos Herrán, 2002, 168169; Cruz, 2009, II, 187-188).

$\mathrm{O}$ único fragmento algarvio identificado (Figura $7, n^{0} 1$ ) corresponde a um fundo côncavo, cujas características do perfil e da orientação, bem como o diâmetro da base, permitem concluir que se trataria da variante globular.

Mais difícil foi a classificação de outros fragmentos pertencentes à categoria dos boiões, que, ainda assim, identificámos como forma 68 de Isings.

A forma reporta-se a pequenos boiões ou "jarrinhas" globulares, de fundo ligeiramente côncavo e bordo horizontal ou em aba pendente. A morfologia do bordo destes recipientes aparenta uma grande diversidade, com exemplares de bordo repuxado para fora e novamente para dentro, sem chegar a enrolar em tubo, para os quais foi proposto por Mário da Cruz uma produção local/regional (Cruz, 2001, 73), ou engrossado ao fogo, em aba horizontal. Não obstante, um colo baixo e estreito é comum a todas as variantes.

Segundo a cronologia proposta por Isings, esta forma foi bastante comum durante os reinados dos Flávios e também durante todo o século II (Isings, 1957, 89), dado apoiado por recipientes exumados em contexto de Ventimiglia, Pompeia, Herculano e Locarno (Ibidem).

Em Castro Marim foram recuperados três fragmentos que considerámos pertencentes a esta for-
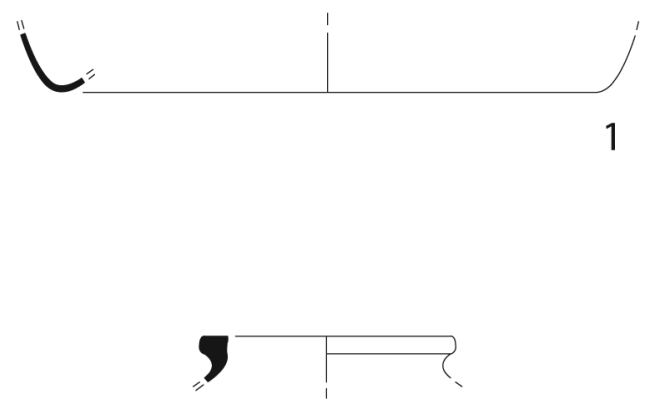

3

Figura 7. Formas sopradas para guardar alimentos. ma. Um deles (Figura 6, no 2) corresponde a um bordo horizontal com uma pequena saliência na extremidade, notando-se ainda a presença do característico colo estreito, o qual apresenta um perfil engrossado. Outros autores consideraram que bordos com esta morfologia podem ser incluíveis em outros tipos da mesma tabela, concretamente os 94 ou 131 de Isings, que se desenvolvem em morfologia distinta, e correspondem a formas mais tardias, século IV/V (Cruz, 2009, II, 199-200). Porém, a hipótese, que tem por base o conjunto bracarense, apresenta, na nossa perspectiva, alguns problemas. De facto, além de os recipientes que apresenta ostentarem claras diferenças morfo-tipológicas com os seus protótipos, nomeadamente o facto de estes terem fundo tubular em pé destacado e aqueles serem simples e côncavos, o fragmento algarvio oferece características técnicas que delatam uma cronologia alto-imperial, concretamente tonalidades esverdeadas translúcidas. Aliás, o mesmo autor não esquece que as formas tardias não se confundem com as congéneres mais antigas, Isings $67 / 68$, pelo bordo distinto e pelas cores carregadas (Ibidem, 200). O fragmento algarvio oferece, precisamente, um bordo semelhante ao que é considerado uma forma tardia, mas com cor igual à dos recipientes alto-imperiais.

Outro exemplar (Figura 7, no 3 ) possui um bordo horizontal e engrossado ao fogo, com a particularidade de o colo ser quase inexistente. Este fragmento é, admitimos, aquele que mais se afasta das características tipológicas dos protótipos, mas,

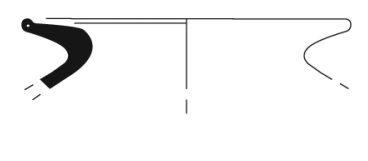

2

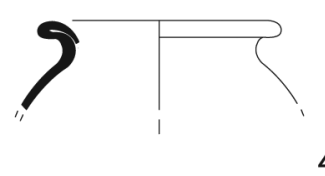

4

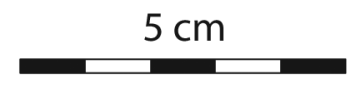


ainda assim, pareceu ser a forma em que melhor se encaixava.

O terceiro bordo (Figura $\left.7, n^{\circ} 4\right)$ não se assemelha a nenhum dos anteriores, estando redobrado para o interior, não chegando a formar uma configuração tubular, morfologia para a qual Mário da Cruz propõe uma eventual produção local em Bracara Augusta (2009, II, 193). Curiosamente, este investigador inclui estes recipientes na forma 67 de Isings, de morfologia bastante distinta.

\subsection{Formas sopradas para unguentos ou} cosméticos

Como na maioria dos sítios de cronologia alto-imperial (Baradez, 1969, 103-104; Bolla, 1988; 1995; Salinas Pleguezuelo, 2003, 44-64; Salinas Pleguezuelo e Salinas Villegas, 2005; Heredia Bercero, 2007, 18-19), os unguentários são, quase sempre, os artefactos mais abundantes nos conjuntos vítreos.

Estes recipientes, destinados, na maioria das vezes, à contenção de unguentos ou de cosméticos, oferecem uma grande variedade morfológica e tipológica. Este facto foi muito facilitado pela simplicidade de fabrico destes recipientes tubulares, sendo suficiente o sopro livre, em algumas formas prensados contra superfícies lisas para obter os fundos planos, como é o caso da forma 82 de Isings.

A forma Isings 8 é um dos tipos mais frequentes, não só nas necrópoles romanas como também nos sítios de habitat, ainda que nestes apareçam mais fragmentados. Ainda assim, a sua identificação é possível devido à conservação do típico fundo em gota (Figura 8, n⿳⺈ 1), específico desta forma, ou do bordo (Figura 8, n⿳⺈ 2). Morfologicamente, poder-

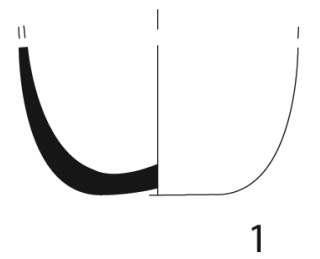

se-ão descrever como unguentários em forma de tubo, com a base convexa em forma de gota, colo alto e estreito, por vezes separado do corpo por uma constrição mais ou menos acentuada, e bordo exvertido de aresta cortada para separação da cana de sopro.

É consensual que estes unguentários de vidro têm uma cronologia maioritariamente de século I (Isings, 1957, 24), embora seja provável que alguns possam ser recolhidos em contextos de início do II (Salinas Pleguezuelo, 2003, 44; Regalado Ortega et alii, 2013, 1712). Apesar de alguns autores proporem uma possível evolução dentro deste tipo (Alarcão, 1970, 254; Cruz, 2009, II, 207), especialmente tendo em consideração a presença ou ausência de estrangulamento do colo, não foi ainda conseguida uma linha evolutiva clara. Certo é que parecem imitar os unguentários cerâmicos, tendo contribuído para a sua extinção a partir, sobretudo, do reinado de Cláudio. Parece também seguro que a sua imposição nos mercados, substituindo os unguentários cerâmicos, foi gerando pequenas produções destinadas a abastecimentos regionais ou supra-regionais (Cruz, 2009, II, 207-208).

Os centros produtores da Lusitânia e da Bética, províncias onde se supõe que foram fabricados, são mal conhecidos. Ainda assim, em Venta del Carmen, Barrios, Cádis (Bernal Casasola, 1997; 2004; Fuentes Domínguez, 1998, 255 e ss.; Beltrán Lloris, 2004, 17), foi identificado um forno destinado à sua produção (Fuentes Domínguez, 1998, 255 e ss.; Bernal Casasola, 1998, 399 e ss.; Beltrán Lloris, 2004, 26), para além de se ter recolhido um abundante espólio vítreo com defeitos de fabrico.

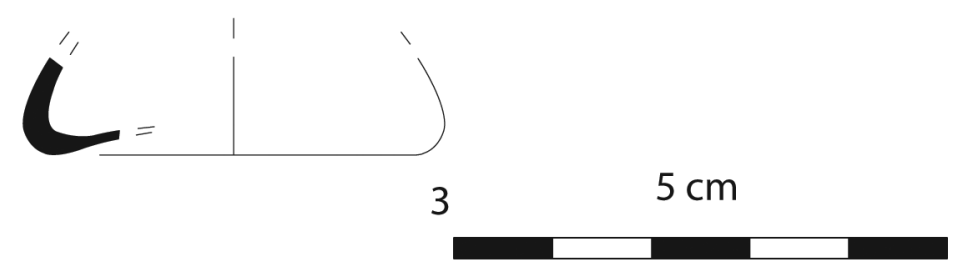

Figura 8. Formas sopradas para conter unguentos ou cosméticos. 
A forma 82 de Isings corresponde ao tipo que logrou um maior sucesso produtivo e comercial durante o Alto-Império, não apenas pela grande variedade de peças que oferecia (variantes A e B), mas sobretudo pela multiplicidade funcional que proporcionava.

A forma 82B1 de Isings $(1957,98-99)$ não é um tipo muito comum de unguentários. Todavia, um fragmento de Castro Marim foi integrado nesta forma (Figura 8, n⿳0 3). Trata-se de unguentários estreitos e altos, de reservatório campanado ou cónico e de reduzidas dimensões. O colo é muito estreito e alto, com uma constrição que o separa do reservatório, e o bordo apresenta-se exvertido, aplanado ou ligeiramente engrossado ao fogo. A base é, geralmente, côncava.

A cronologia dos unguentários tubulares não é muito díspar entre si, especialmente dos da forma 82 de Isings. Esta variante em concreto encontra ainda paralelo na forma AR 135 (Rütti, 1991, 53) e na Trier 73 (Goethert-Polaschek, 1977, 350), tipos com uma datação consensual entre final do século I e meados do século II (Cruz, 2009, II, 213; Alonso Cereja, 2010, 326), existindo alguns contextos mais tardios (Alonso López e Méndez Grande, 2013, 1674-1675). No entanto, lembramos que os exemplares de Riotinto, Huelva, firmados com a marca PRO.MANC.B.C.AR, oferecem contextos mais antigos, concretamente a partir de final do primeiro terço do século I (Regalado Ortega e Delgado Domínguez, 2011, 727, nº 2.4 e 2.5).

\subsection{Formas de difícil classificação}

Em Castro Marim, existe ainda uma série de fragmentos de vidro de difícil classificação, situação que resulta, por um lado, do seu estado de fragmentação e, por outro, da ausência de formas similares nas tipologias. Efectivamente, a primeira justificação é, como repetimos por várias vezes, aquela que mais se fez sentir à medida que tentávamos enquadrar estes fragmentos no comércio de consumo de Baesuris.

Um fragmento (Figura 9, $\mathrm{n}^{\mathrm{0}}$ 1), que conserva ainda o bordo, deverá corresponder a um pequeno pote, ou a uma pequena urna. Apresenta como principais características um perfil em $\mathrm{S}$, devido ao facto de corresponder a um bordo dobrado para fora e novamente para dentro, formando uma saliência interna que poderá ter servido de apoio a uma tampa. É um bordo duplamente tubular, de secção arredondada, que denuncia um desenvolvi- mento para uma forma fechada, globular, de paredes bastante finas.

Também outro fragmento (Figura 9, no 2) foi considerado um bordo tubular, mas de dimensões bem mais reduzidas, pelo que se poderá tratar de uma jarra ou de uma garrafa. Pode, porém, ter feito parte da mesma peça que o fundo côncavo, de pé horizontal saliente (Figura 9, n⿳⺈ 3), caso tivesse sido possível garantir que tinham pertencido a um copo.

Se não podemos indicar a forma a que pertenceram muitos destes fragmentos, alguns permitem, pelo menos, intuir a categoria a que terão pertencido (Figura 9, no 4 e 5). O primeiro trata-se de um fundo duplamente tubular, de base plana, que terá pertencido a uma pequena taça ou tigela. $\mathrm{O}$ segundo corresponde a um bordo de forma aberta, que considerámos da mesma categoria. Tem um pequeno vinco na parte exterior.

Mais inconclusivos são os restantes (Figura 9, $\mathrm{n}^{\mathrm{O}}$ 6 a 9). $\mathrm{O} \mathrm{n}^{0} 6$ parece tratar-se de uma base plana com círculos em relevo na parte superior, característica que permite considerar como possível ter pertencido a um copo de tipo cálice. $\mathrm{O} \mathrm{n}^{0} 7$, um fundo côncavo, pode ter feito parte de uma garrafa ou jarra, ou mesmo de uma tampa. Não podemos deixar de referir, contudo, que a ausência de uma pega ou do seu arranque exclui, quase liminarmente, a primeira das hipóteses, sendo a segunda mais provável, ainda que a ser garrafa ou jarra a concavidade devesse ser mais pronunciada.

Os fragmentos $\mathrm{n}^{\mathrm{0}} 8$ e 9 são muito reduzidos. Apesar disso o último pode ter correspondido a um pote globular de bordo aplanado e perfil oblíquo da forma 94 de Isings.

Para os dois fragmentos decorados (Figura 9, $\mathrm{n}^{\mathrm{o}} 10$ e 11) não encontrámos paralelo. No primeiro caso, estamos perante uma pequena saliência em espinha, que parece uma asa cega.

No conjunto de Castro Marim existem ainda quatro fragmentos de asa (Figura 9, n⿳0 12 a 15), que, devido ao seu estado de fragmentação, não foi possível classificar.

\subsection{Objectos de adorno}

Em Castro Marim foi possível recuperar dois fragmentos de pulseiras de vidro (Figura 10, n⿳0 1 e 2).

Uma delas $\left(\mathrm{n}^{\mathrm{o}} 2\right)$, de secção maciça semicircular, e aro liso, corresponde ao tipo de pulseiras mais comum em época romana.

Mais raras são as de secção circular, que podem ostentar uma ou mais tonalidades opacas, geral- 


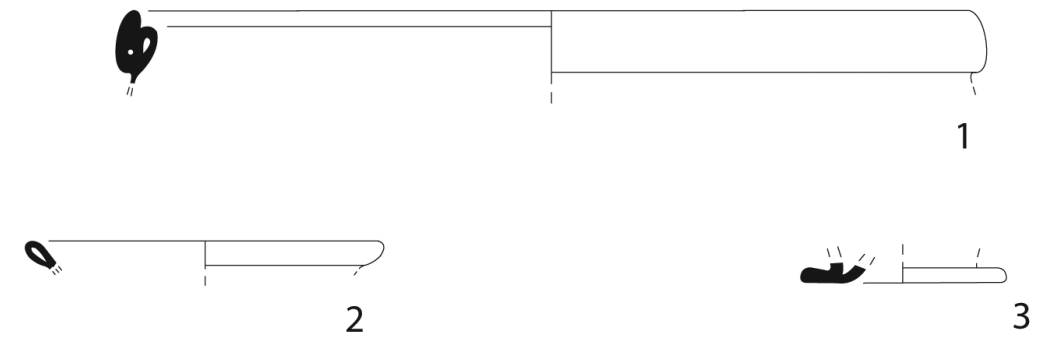

-2.

4

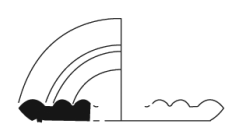

6

8

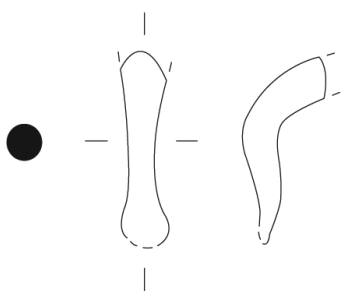

12

$-\prod_{1}^{1}-\int_{1}^{1}$

14
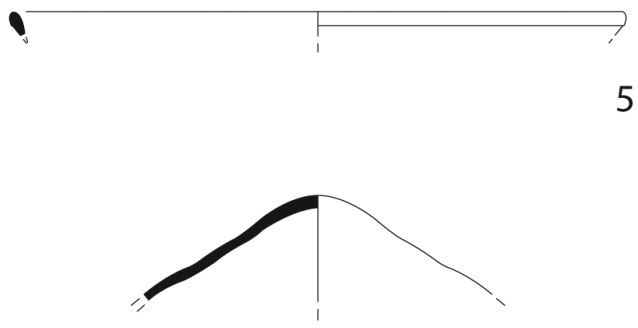

7

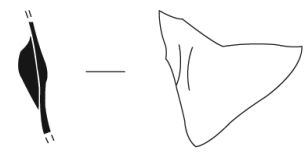

$n_{11}^{\prime}-\square$

10

11

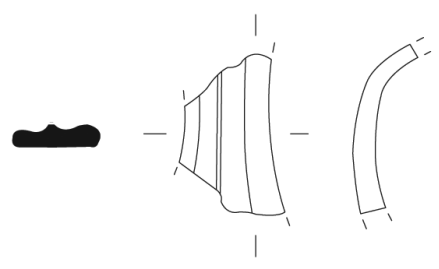

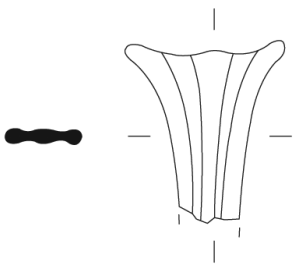

15

$5 \mathrm{~cm}$

Figura 9. Formas de classificação indeterminada. 


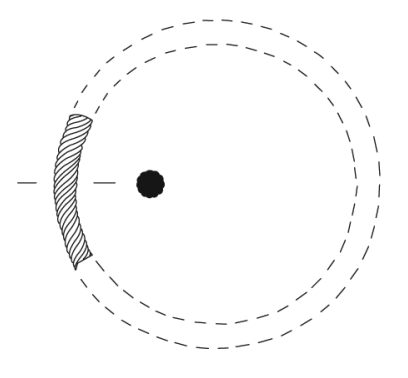

1

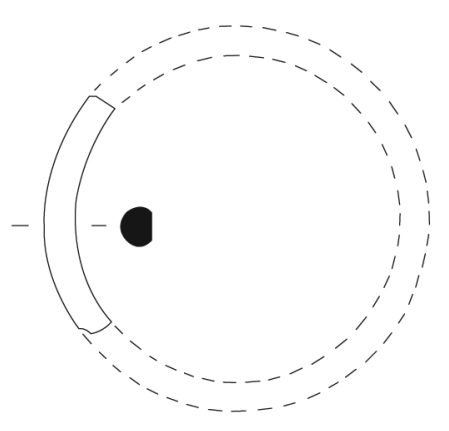

2

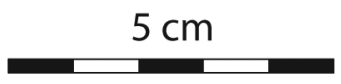

Figura 10. Artefactos de adorno pessoal.

mente o azul, negro ou amarelo. São peças de fabrico similar ao das cânulas de vidro, obtidas por torção, sendo posteriormente enroladas em um objecto circular. Estas peças têm similitudes com o tipo III definido para os braceletes de Conímbriga (França, 1969, 35). O exemplar castromarinense é de uma só tonalidade ( $\left.\mathrm{n}^{\mathrm{o}} 1\right)$, negro opaco, mas que preenche todas as outras características. Além disso, tem uma diâmetro reduzido, pelo que supomos ter pertencido a uma criança ou adolescente.

Foi já referido (Cruz, 2009, I, 148) que estes artefactos não são os melhores indicadores cronológico-culturais. Com efeito, "o seu reduzido tamanho, valor e resistência ao tempo e às modas, faz com que viajem facilmente a longas distâncias e perdurem no tempo" (Ibidem).

\section{REFLEXÕES FINAIS}

Apesar dos vários constrangimentos que enfrentámos, nomeadamente os que se prendem com a ausência de contexto arqueológico para a maioria das peças estudadas e com o estado de fragmentação do conjunto, o presente estudo permite algumas observações finais que parecem relevantes para a análise da ocupação romana do oppidum algarvio.

Em primeiro lugar, deve destacar-se o reduzido volume do conjunto vítreo. Tal facto, poderia parecer surpreendente, uma vez que a presença romana no Castelo de Castro Marim está confirmada por um numerosíssimo espólio e as áreas escavadas são amplas. Contudo, os níveis correspondentes à ocupação Alto-Imperial são infinitamente mais ténues do que os republicanos, e estão muito mais mal conservados. Reiterámos, por várias vezes ao longo do trabalho, o facto de a grande maioria destes fragmentos ter sido recuperada em níveis estratigráficos de cronologia Medieval ou Moderna. Tal situação impossibilitou, à partida, obter dados concretos acerca dos contextos de recolha.

Por outro lado, a elevada fragilidade do vidro e a sua reciclagem, confirmada, por exemplo, na província da Britânia (Price e Cool, 1991, 26-27), podem, igualmente, justificar a sua escassez no sítio. Estudos recentes têm vindo, cada vez com mais frequência, a evidenciar o facto de, na Antiguidade, os artesãos terem sabido tirar partido da reciclagem, situação que “...ora faz «desaparecer» o vidro dos sítios arqueológicos ora mistura vidro de diferentes origens numa mesma oficina." (Cruz, 2011, 84).

Não podemos também deixar de insistir nos aspectos cronológicos do conjunto. Como se pôde constatar na análise efectuada nas páginas anteriores, a maioria das formas foi balizada entre meados da primeira metade do século I e o primeiro terço do seguinte. Tal datação não surpreende, até porque o estudo da cerâmica de mesa (Viegas, 2011) deixou ler a mesma realidade e "...os conjuntos de cerâmicas do Alto-Império permitem verificar que o sítio permaneceu com intensa actividade..." (Ibidem, 518). De facto, quer na primeira metade do século I quer na segunda, as importações de sigillata itálica, primeiro, e sudgálica, depois, são muito expressivas em termos numéricos (Ibidem). O mesmo estudo possibilitou também reconhecer o abandono 
do sítio no final do século I/início do II, o que justifica a pouca expressão da terra sigillata hispânica (Ibidem) e poderá ter sido uma das causas que contribuiu para a fraca representatividade de artefactos de vidro a partir de então. Todavia, apesar da forte redução no consumo e utilização de artefactos de vidro, existem alguns que podem datar-se de momentos posteriores ao século II d.C.

Para além dos aspectos morfológicos, a própria coloração dos vidros de Castro Marim também proporcionou a mesma leitura cronológica. Lembramos que a grande maioria dos artefactos estudados ostenta tonalidades esverdeadas translúcidas ou incolores translúcidas, que têm sido associadas a momento alto-imperial. Como é conhecido, a reciclagem do vidro fomentou o aparecimento de novas tonalidades, resultantes de reacções químicas, que são facilmente identificadas pelo seu escurecimento gradual e também pelo aparecimento de outras cores, como os amarelos ou castanhos-escuros, que antes não existiam.

Ainda no que diz respeito aos aspectos cronológicos, devemos referir também que algumas peças ostentam estas tonalidades tardias, o que, associado à presença de algumas formas concretas, comprova uma ocupação tardia da colina do castelo de Castro Marim (Figura 11), facto que, uma vez mais, o estudo da cerâmica fina e das ânforas já tinha ajudado a presumir (Viegas, 2011, 520). Assim, embora os artefactos vítreos se enquadrem entre os séculos I e IV d.C., foi durante os dois primeiros, após a viragem da Era, que constatámos a maior actividade comercial.
Parece importante, neste contexto, deixar claro que a maioria das tipologias sobre os vidros romanos foi elaborada na primeira metade do século XIX. Por outro lado, é grande o desconhecimento sobre estes artefactos, especialmente sobre as oficinae que terão laborado em território hispânico, questão que foi recentemente abordada no âmbito da análise do vidro romano do Noroeste peninsular (Cruz, 2009, I, 167-276). Infelizmente, o conjunto agora analisado não contribuiu com novos dados cronológicos, nem sequer permitiu afinar os que, sendo conhecidos, têm uma amplitude estranhamente dilatada.

O conjunto dos vidros romanos recuperados no Castelo de Castro Marim não é particularmente diversificado do ponto de vista funcional. De facto, e ainda que tipologicamente se tenha observado um número considerável de formas, estas resumem-se a seis grupos: copos, taças e/ou tigelas, pratos, garrafas ou jarras, boiões e unguentários. São assim os artefactos mais comuns em sítios romanos ocupados durante o Alto-Império. As taças e/ou tigelas são as classes mais representadas (figura 11), correspondendo ao dobro das restantes. Seguem-se os copos e as garrafas, curiosamente em número idêntico, o que comprova, em nosso entender, que são classes que se complementam. Já os pratos são meramente residuais, como acontece, aliás, na maioria dos sítios romanos.

Os artefactos de vidro destinados ao consumo de alimentos foram, em Baesuris, os mais utilizados, sendo mais escassos aqueles que estariam destinados

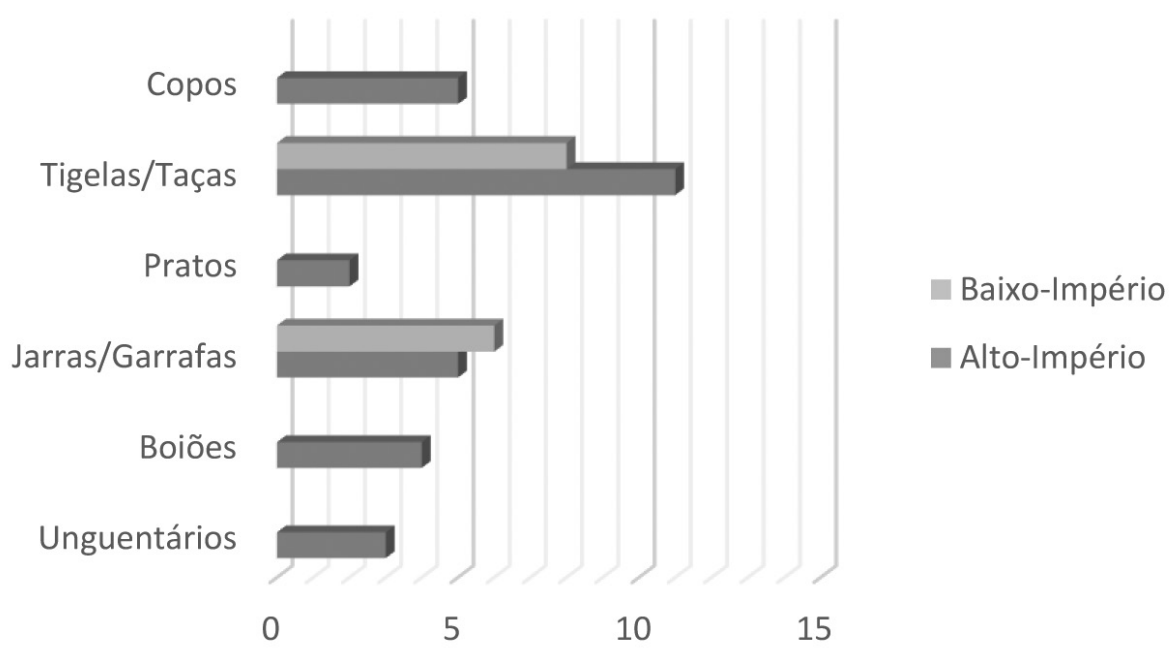

Figura 11. Distribuição dos vidros romanos de Castro Marim por categorias. 
ao armazenamento, quer de alimentos quer de outros produtos (unguentos, cosméticos ou fármacos). Note-se, contudo, que, daqueles, apenas uma forma se pôde associar, inequivocamente, ao consumo de alimentos sólidos (prato), estando os restantes (copos, taças, garrafas, jarras) relacionados com o serviço e/ou ingestão de líquidos. Esta situação não é rara, e mesmo em sítios com uma considerável presença de artefactos de vidro ela é recorrente.

Aglomerados urbanos, como aquele que existiu na colina do Castelo de Castro Marim, apresentam, geralmente, um consumo de utensílios de vidro directamente relacionado com alimentos líquidos e contentorização de fármacos ou cosméticos. Esta realidade, que poderia traduzir um reduzido poder aquisitivo, deve ser, contudo, avaliada tendo em atenção a já comentada reciclagem do vidro.

Mais difícil é atribuir uma origem às peças a que estes fragmentos pertenceram, observação que depende bastante de outro tipo de análises. De facto, uma análise meramente técnico-morfológica não é suficiente na atribuição de uma origem para a produção de determinada peça. Todavia, a distribuição formal do conjunto não parece denunciar origens atípicas, situação que vem sendo apontada para casos de formas raras (Alonso López e Mendéz Grande, 2013, 1677-1681). Assim, não estando actualmente reconhecida, no Algarve, qualquer actividade vidreira em época romana, deve ter-se em conta que à província romana da Bética é apontada a existência de tais labores (Vigil Pascual, 1969, 89; Caldera de Castro, 1983, 13; Fuentes Domínguez, 1998, 255 e ss.). Aliás, o vale do Guadalquivir é a área que mais tem sido citada, e à qual se atribui, inclusive, uma considerável produção de unguentários, principalmente aqueles marcados com as siglas AVG e PRO.MANC.B.C.AR (Price, 1977), presentes no Algarve (Pereira, 2014, 143-144).

A capital da Lusitânia também é apontada como um centro onde se registou a produção de artefactos de vidro (Caldera de Castro, 1983, 65-68). Porém, o foco para a origem a ter-se em consideração para este conjunto algarvio deve incidir nas produções Béticas. Recorde-se que, ainda que o Algarve tenha integrado a província da Lusitânia, foi com a Bética que manteve uma actividade comercial intensa e permanente. Repetimos, contudo, que atribuir uma origem a estes recipientes é arriscado.
Bibliografia

Alarcão, J. de (1968), "Vidros romanos dos museus do Alentejo e Algarve", Conimbriga, 7, 1-33.

(1970), "Vidros romanos de Balsa", O Arqueólogo Português, $3^{\text {a }}$ Série/4, 237-273.

(1976), "Vidros romanos procedentes da colecção do rei D. Manuel", Conimbriga, XV, 55-68.

Alarcão, J. de e Alarcão, A. (1965), Vidros romanos de Conimbriga, Coimbra.

Alarcão, J. de, Delgado, M., Mayet, F., Alarcão, A. e Ponte, S. (1976), Fouilles de Conimbriga - VI - Céramiques diverses et verres, Paris.

Alonso Cereza, E. (2010), El vidrio romano en los museos de Madrid. Tese apresentada à Universidad de Madrid para obtenção do grau de Doutor.

Alonso López, J. e Méndez Grande, G. (2013), “El vidrio romano de una de las áreas funerarias al sur de Augusta Emerita”, Actas do VI Encuentro de Arqueología del Suroeste Peninsular, Villafranca de los Barros, 1655-1689.

Alvar Nuño, A. (2010), El mal de ojo en el occidente romano: materiales de Italia, Norte de África, Península Ibérica y Galia. Tese apresentada à Universidad Complutense de Madrid, Facultad de Geografía e Historia, para obtenção do grau de Doutor.

Antunes, A. (2000), "Vidros romanos da Alcáçova de Santarém", Revista Portuguesa de Arqueologia, 3/2, 153-197.

Arruda, A. (1999/2000), "Los Fenicios en Portugal. Fenicios y Mundo indígena en el Centro y Sur de Portugal (siglos VIII-VI a.C.)", Cuadernos de Arqueología Mediterránea, 5-6, 78-238.

(2008), "O Baixo Guadiana durante os séculos VI e V a.n.e.", SIDEREUM ANA. El rio Guadiana en época post-orientalizante (J. Jiménez Ávila, Ed.), Anejos de Archivo Español de Arqueología, XLVI, Mérida, 317-322.

Arruda, A. e Freitas, V. (2008), "O Castelo de Castro Marim durante os séculos VI e V a.n.e.”, SIDEREUM ANA. El rio Guadiana en época postorientalizante, (J. Jiménez Ávila, Ed.) Anejos de Archivo Español de Arqueología, XLVI, Mérida, 430-444.

Arruda, A., Freitas, V. e Oliveira, F. (2007), "Os Fenícios e a Urbanização no Extremo Ocidente: o caso de Castro Marim”, Las ciudades feníciopúnicas en el Mediterráneo (J.L. López Castro, Ed.), Almería, 464-471. 
Arruda, A., Viegas, C., Bargão, P. e Pereira, R. (2006), “A importação de preparados de peixe em Castro Marim: da Idade do Ferro à Epoca Romana”, Setúbal Arqueológica, 13, 153-176.

Baradez, J. (1969), "Nécropole orientale côtière de Tipasa de Maurétanie”, Antiquités Africaines, 3, 83-113.

Beltrán Lloris, M. (2004), “Alfares y hornos romanos en Andalucía. Historiografía de la investigación y claves de lectura", Talleres alfareros y producciones cerámicas en la Bética romana (ss. II a.C. - VII d.C.). B.A.R., Internacional series, 1266, 9-38.

Berger, L. (1960), Römische Glasser aus Vindonissa, Veröffentlichungen der Gesellchaft pro Vindonissa, IV, Basel.

Bernal Casasola, D. (1997), "La producción anfórica en la bahía de Algeciras en época romana: nuevos datos procedentes de los talleres de la Venta del Carmen (Los Barrios)", IV Jornadas de Historia del Campo de Gibraltar, 17, 6573.

(1998), Excavaciones arqueológicas en el alfar romano de la Venta del Carmen (Los Barrios, Cádiz). Una aproximación a la producción anfórica en la Bahía de Algeciras en época altoimperial, Madrid.

(2004), "Comercio, rutas y navegación en la Hispania meridional tardoromana (ss. III - VII d.C.). Una perspectiva desde la arqueologia litoral”, Rotte e porti del Mediterraneo dopo la caduta dell'Impero Romano d'Occidente. Continuità e innovazioni tecnologiche $e$ funzionali (L. Maria e R. Turchetti, Eds.), Roma, 33-64.

Bolla, M. (1988), Le necropoli romane di Milano, Milano, Supplemento V.

(1995), "Analisi della necropoli di Cavaion, Bossema", La necropoli romana a Bossema di Cavaion (Salzani, L. ed.), Verona.

Buora, M., Mandruzzato, L. e Verità, M. (2009), "Vecchie e nuove evidenze di officine vetrarie romane ad Aquileia”, Quaderni Friulani di Archeologia, XIX, 51-58.

Caamaño Gesto, J. M., Xulio Carballo, L. e Ángeles Vásquez, Maㅗ (2007), “Aproximación arqueológica al poblado galaico-romano de Santa Trega (A Garda, Pontevedra) a través del estudio del material vítreo", Gallaecia, 26, 109131.

Caldera de Castro, M. (1983), "El vidrio romano emeritense”, Augusta Emerita I, 7-80.

Campos Carrasco, J., Gómez Rodríguez, A., Rodríguez Pujazón, R., Medina Rosales, N., Delgado Aguilar, S., O’Kelly Sendrós, J., Cortijo Romero, V. e Vidal Teruel, N. (2009), "Investigación y puesta en valor de la ciudad hispanorromana de Turobriga (Aroche, Huelva). Intervención puntual 2004”, Anuario Arqueólogico de Andalucía, 2004/1, 16331652.

Chiriac, C. e Boțan, S. (2014), "Roman Glass Vessels in the Western Pontic Area (1st-3rd Centuries CE). General Remarks”, Interconnectivity in the Mediterranean and Pontic World during the Hellenistic and Roman Periods (V. Cojocaru, A. Coşkun, e M. Dana, Eds.), Pontica et Mediterranea, III, 525-554.

Cool, H. e Price, J. (1995), Roman vessel glass from excavations in Colchester, 1971-85, Colchester Archaeological Report 8, Colchester.

Cruz, M. (2001), Os vidros romanos de Bracara Augusta. Dissertação apresentada à universidade do Minho para obtenção do grau de Mestre.

(2009), O Vidro Romano no Noroeste Peninsular. Um olhar a partir de Bracara Augusta. Dissertação apresentada à universidade do Minho para obtenção do grau de Doutor.

(2011), "Fragmentos de vidro, fragmentos da memória. Aproximação à actividade vidreira em Bracara Augusta”, Cultura, Espaço \& Memória, 2, 83-94.

Domínguez-Arranz, A. e Ortiz Palomar, E. (20022003), "Um vaso de vidrio tardohelenístico procedente del yacimiento de Bibracte, Mont Beauvray, Borgoña", Lucentum, XXI-XXII, 75-85.

Fernández Matallana, F. e Crespo Ros, M. (1996), "Una colección de vidrios romanos procedente de Calahorra (La Rioja)", Kalakorikos, 1, 1324.

Foy, D. (1995), "Le verre de la fin du IVe au VIIIe siecle en France mediterraneenne, premier essai de typo-chronologie”, Le Verre de L'Antiquité Tardive et du Haut Moyen Age. Typologie Chronologie Diffusion, Guiry-en-Vexin, 187242.

Foy, D. e Nenna, M. D. (2001), Tout feu tout sable. Mille ans de verre antique dans le Midi de la France, Aix-en-Provence.

França, A. (1969), "Anéis, braceletes e brincos de Conímbriga”, Conimbriga, VIII, 17-68. 
Fremersdorf, F. (1932), Alexandrinisches Buntglas aus einer Grabummauerung in Köln, 16, Germania.

(1958), Das Naturfarbene Soogenamte Blaugrüne Glas in Koln, 5, Cologne.

Fuentes Domínguez, A. (1998), "El vidrio: estudio de los restos de fabricación de un taller de unguentários”, Excavaciones arqueológicas en la Venta del Carmen (Los Barrios, Cádiz): una aproximación a la producción de ánforas en la bahía de Algeciras en época altoimperial (D. Bernal Casasola, Coord.), Cádiz, 255-276.

Girard, P. (2010), Le verre antique: Usages et techniques. Le Proche-Orient, creuset de l'innovation verrière?, Mémoire de Master d' archéologie II réalisé à l'Université Paul ValéryMontpellier III dirigé par Madame Bletry Sylvie.

Goethert-Polaschek, K. (1985), Katalog der römische Lampen des Rheinischen Landesmuseums Trier, Mainz.

Harden, D. (1936), Roman glass from Karanis found by the University of Michigan Archaeological Expedition in Egypt, 192429, Michigan.

(1947), "The glass", Camulodunum. First report on the excavations at Colchester 1930-1939 (Hawkes. C. ed.), London, Reports of the Research Committee, 14, 287-307.

Heredia Bercero, J. (2007), "La via sepulchralis de la Plaza Vila de Madrid. Un ejemplo del ritual funerario durante el alto imperio en la necrópolis occidental de Barcino", Quarhis, II, 3, 12-63.

Isings, C. (1957), Roman Glass from dated Finds, Jacarta.

Jeremic, G. (2009), Saldum, Roman and Early Byzantine fortification, Institut Archéologique, Belgrade.

Kisa, A. (1908), Das Glas im Altertume, Leipzig.

Leljak, M. (2012), "Typology of the Roman glass vessels from the Croatian part of the province Pannonia”, Haemus Journal, 1, 121-133.

Lith, S. e Randsborg, K. (1985), Roman glass in the West: a social study, Amesterdão.

Marcos Herrán, J. (2002), Vidrios romanos de Herrera de Pisuerga: Palencia, Palencia.

Mauri, A. (1933), La casa del Menandro e il suo tesoro di argenteria, Roma.

Morin-Jean, J. (1913), La Verrerie en Gaule sous
l'Empire Roman. Essai de morphologie et de chronologie, Paris.

Nolen, J. (ed.) (1994), Cerâmicas e vidros de Torre de Ares, Balsa, incluindo o espólio ósseo e medieval, Lisboa.

Pereira, C. (2012), "Vidro: breve análise temporal e técnica", Al-Madan, 17, Adenda electrónica.

(2014), As necrópoles romanas do Algarve. Acerca dos espaços da morte no Extremo Sul da Lusitânia, Dissertação apresentada à Faculdade de Letras da Universidade de Lisboa para obtenção do grau de Doutor.

Pereira, T. (2008), Os Artefactos Metálicos do Castelo de Castro Marim na Idade do Ferro e em Época Romana, Dissertação apresentada à Faculdade de Letras da Universidade de Lisboa para obtenção do grau de Mestre.

Price, J. (1977), "Roman unguent bottles from Rio Tinto (Huelva) in Spain”, Journal of Glass Studies, XIX, 30-39.

Price, J. e Cool, H. (1991), "The evidence for the production of glass in Roman Britain”, Ateliers de verriers de l'antiquité à la période préindustrielle (D. Foy e G. Sennequier, Eds.), Association Française pour l'Archéologie du Verre, Rouen, 23-30.

Price, J. e Cottam, S. (1998), Romano-British Glass Vessels: a Handbook, York.

Regalado Ortega, Ma e Delgado Domínguez, A. (2011), "La colección de vidrios romanos del museo minero de Riotinto (Minas de Riotinto, Huelva)", Río Tinto. Historia, Patrimonio Minero y Turismo Cultural(J.A. Pérez Macías, A. Delgado Domínguez, J.M. Pérez López, F.J. García Delgado, Eds.), Huelva, 719-734.

Regalado Ortega, M., Delgado Domínguez, A. e Lagares Rivero, J.(2013), "Vitrum Metallorum: vidrio romano en el Cinturón Ibérico de Piritas”, Actas do VI Encuentro de Arqueología del Suroeste Peninsular, Villafranca de los Barros, 1691-1727.

Rütti, B. (1991), Die römischen Gläser aus Augst und Kaiseraugst, Forschungen in Augst, Band 13.

Salinas Pleguezuelo, $\mathrm{M}^{\mathrm{a}}$ (2003), El vidrio romano de Córdoba, Arqueología Cordobesa, 8, Córdoba.

Salinas Pleguezuelo, Mª e Salinas Villegas, J. (2005), "Vidrio romano en un sector de la necrópolis septentrional de Colonia Patricia”, Anales de Arqueología Cordobesa, 16, 143-160. 
Scatozza, L. (1995), I vetri romani di Ercolano, Roma.

Simonett, C. (1941), Tessiner Graberfelder Monographien zururund Frughgerschichte de Schweitz Herausgegeben von der Schweizerischen Gesselhalt für urgeschichte, Band III, Basel.

Viegas, C. (2006), "A ocupação romana de Castro Marim”, Xelb, 6/1., I, 241-260.

(2011), A ocupação romana do Algarve. Estudo do povoamento e economia do Algarve central e oriental no período romano, Lisboa.

Vigil Pascual, M. (1969), El vidrio en el Mundo Antiguo, Madrid. 